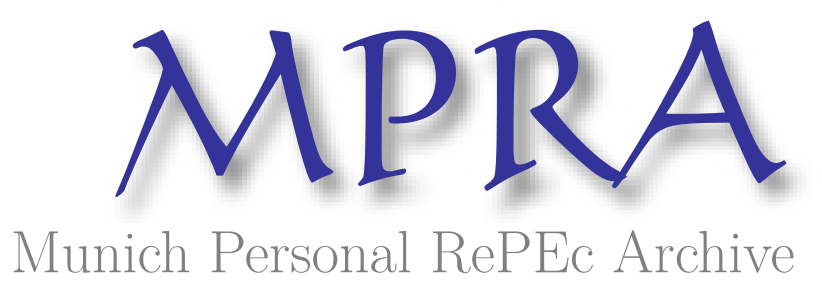

Structural changes in exchange rate-stock returns dynamics in South Africa: Examining the role of crisis and new trading platform

Phiri, Andrew

10 April 2018

Online at https://mpra.ub.uni-muenchen.de/85826/

MPRA Paper No. 85826, posted 11 Apr 2018 07:11 UTC 


\title{
STRUCTURAL CHANGES IN EXCHANGE RATE-STOCK RETURNS DYNAMICS IN SOUTH AFRICA: EXAMINING THE ROLE OF CRISIS AND NEW TRADING PLATFORM
}

\author{
A. Phiri \\ Department of Economics, Faculty of Business and Economic Studies, Nelson Mandela \\ Metropolitan University, Port Elizabeth, South Africa, 6031.
}

\begin{abstract}
The 2007 sub-prime crisis and the adoption of Millennium trading platform represent two of the most important recent structural developments for the Johannesburg Stock Exchange (JSE). Under an environment of flexible and volatile exchange rates, this study seeks to examine the effects of these two structural events on the exchange rate-equity returns nexus for 4 JSE indices using the nonlinear autoregressive distributive lag (N-ARDL) cointegration. We use monthly data collected from 2000:M01 to 2017:M12, and conduct our empirical analysis over sub-periods corresponding to breaks caused by the crisis and the use of a new trading platform. We find prior the crisis exchange rates appreciations generally cause stock returns whereas depreciations are unlikely to cause stock returns to decrease. However, during crisis period this relationship entire disappears whilst resurfacing subsequent to the adoption of a new trading platform although the dynamics of the time series differs between sectors. Our overall empirical results caution regulatory authorities to closely monitor stock market developments as the new trading platform offers market participants opportunities of using the exchange rate to beat the market.
\end{abstract}

Keywords: Stock returns; Exchange rates; High frequency trading; Millennium trading platform; N-ARDL model; Flexible Fourier form unit root test; South Africa; Emerging economies.

JEL Classification Code: C13; C32; C51; G01, G10. 


\section{INTRODUCTION}

The world has experienced increasing global financial integration over the last couple of decades or so, mainly in the form of financial liberalization and improved international capital flow movements. This became exceedingly apparent following the infamous crash of the US financial system triggered by the sub-prime mortgage crisis of 2008 , which had contagion spill-over effects to financial markets worldwide. The most immediate international effects of the sub-prime crisis were exerted on the dollar exchange rate with other international currencies as well as on stock markets globally. It is for this reason that many economists have recently taken a keen interest on the empirical relationship between the exchange rate and stock market returns (Bahmani-Oskooe and Saha $(2015,2016,2018)$ ).

Even though it is widely acknowledged that the adverse effects of the global financial crisis has varied across financial markets worldwide, the general consensus is that African financial systems responded more resiliently towards the aftereffects of the crisis. Notably, many African economies are characterized by underdeveloped stock markets and monetary authorities in a number of these countries have attempted to keep currency exchanges competitive by relying on floating exchange rate policies as guided by the "Washington consensus". Thus far, the contagion effects arising from the financial crisis have not severely altered stock market dynamics in less developed African stock exchanges seeing that many of these stock markets are not well integrated with other international financial and capital markets. However, many African currencies have turned out to be quite volatile against the US dollar following the 2007 sub-prime crisis and the more recent oil price hikes of 20122014 and this, by itself, poses as a major threat to financial as well as economic stability in these economies.

In retrospective, the South African economy presents a unique case for the African continent as her financial system is characterized by a blend of a mature stock market and a highly institutionalized 'full-fledged' inflation targeting regime monetary policy framework. In particularly contributing to her reprotoire, South Africa arguably has the most developed 
equity markets on the continent, with the Johannesburg Stock Exchange (JSE) boasting the highest market capitalization in Africa, with the highest number of cross-listed firms on the continent and being the only country to have incorporated high frequency trading (HFT) trading mechanism into trading platforms in 2013 (Phiri, 2016). This later feature not only represents a technological advantage over other African economies but more importantly represents a structural change in trading dynamics with respect to the major improvement in speed and volumes of transactions. Moreover, the country has one of the strongest currencies in the Sub-Saharan African (SSA) region and lists the highest amount of foreign reserves which more-or-less reflects the confidence or preference which foreign entities have in exchanging their domestic currency for South African Rands.

Against these attributes, it is therefore not at all surprising that there have been a handful of previous studies which have examined the relationship between the Rand/Dollar (ZAR/US\$) exchange rate and JSE equity returns (Ocran (2010), Adjasi et. al. (2011), Alam et al. (2011), Ndako (2013), Mlambo et al. (2013), Sui and Sun (2015) and Fowowe (2015)). Nonetheless, these studies suffer a number of shortcomings. Firstly, a majority of those studies tend to rely on linear cointegration frameworks such as such as those presented by Engle-Granger (1987), Johansen (1991) and Pesaran et al. (2001). However, as argued by Bahmani-Oskooee and Saha $(2015,2018)$, given that market participants in stock markets base their decisions on expectations, then most likely exchange rates would have a nonlinear influence on stock prices. Secondly, a number of these studies employ time series corresponding to periods prior to the financial crisis hence ignore the possibility of changing dynamics of the exchange rate-stock returns dynamics caused by the crisis (Ocran (2010), Adjasi et al. (2011) and Alam et al. (2011)). Thirdly, even when studies employ data covering the financial crisis period, the authors fail to adequately account for this structural break primarily due to reliance on linear cointegration models (Ndako (2013), Mlambo et al. (2013), Sui and Sun (2015) and Fowowe (2015)). Fourthly, previous studies have not considered the possibility of a second structural break brought about by the adoption of the Millennium trading platform which has ushered in the 'much-celebrated' high frequency trading mechanism into the JSE (Phiri, 2018). Lastly, these previous studies utilize 
aggregated stock indices which heightens the possibility of aggregation bias associated with these previous studies.

In our study we apply the recently introduced nonlinear autoregressive distributive lag (N-ARDL) model of Shin et al. (2014) to examine nonlinear cointegration between the RandDollar exchange rate and the returns on four JSE stock indices; namely the i) the All-Share index ii) the Top.40 index iii) the financial 25 index and iv) the Resource.10 index. The NARDL models main appealing feature is that in similarity to its linear predecessor, the ARDL model of Pesaran et al. (2001), this framework permits the modelling of long-run and shortrun asymmetric cointegration effects between a combination of levels and first difference stationary variables. Notably, this model framework has been successfully used to model short-run and long-run asymmetric cointegration relationships between stock returns and exchange rates for the industrialized and other emerging economies (Cuestas and Tong (2015), Bahmani-Oskooee and Saha $(2015,2017,2018)$ and Tong (2018)) but is yet to be applied to African time series. We therefore contribute to this emerging group of literature by employing the N-ARDL framework to South African monthly time series covering the post Asian financial crisis period of 2000:M01 to 2017:M12 and further account for the 2007 financial crisis and the adoption of the new Millennium trading platform in our analysis.

Having provided a background, the remainder of the study is structured as follows. The next section provides a review of the related literature. The third section of the paper presents the empirical data and unit root tests of the time series. The fourth section reports the empirical estimates of the empirical models whereas the paper is concluded in the fifth section of the paper in the form of policy recommendations and avenues for future research.

\section{LITERATURE REVIEW}

Empirical interest concerning the relationship between exchange rates and stock prices gained significant prominence following the demise of the Bretton Woods system and the subsequent adoption of a system of floating exchange rate regimes by Central Banks 
worldwide in the mid-1970's. Further exacerbating the need for such research in the 1980's, were the formation of the Plaza accord agreement of 1985 and the Louvre Accord agreement of 1987 which aimed to stabilize the international currency market via a devaluation of the dollar against the currencies of G5 economies. It therefore comes as no surprise that a bulk majority of earlier empirical studies which examined the exchange rate-stock price relationship where typically focused on the US economy with the works of Dornbusch and Fischer (1980), Branson (1983), Frankel (1983) and Gavin (1989) being classic theoretical contributions. On one hand, Dornbusch and Fischer (1980) and Gavin (1989), develop the flow-oriented or the goods-market approach to exchange rate determination which assumes that changes in the exchange rates affect international competitiveness and the trade balance, which in turn affects the real output and firm's performance, which is ultimately reflected in stock prices. On the other hand, Branson (1983) and Frankel (1983) propose the stockoriented model or portfolio-balance approach which specifically shows that exchange rates are affected by stock price movements via the capital account since stock market movements lead to money flow into or out of the countries, which affects the demand for money, and thereby leading to changes in interest rates as well as exchange rate movements.

Accompanying these theoretical underpinnings were the earlier prominent empirical contributions of Franck and Young (1972), Aggarwal (1981), Solnik (1987) and Ma and Kao (1990). Nevertheless, the inferences drawn from these earlier studies were branded as unreliable based on the premise of these studies ignoring I(1) stochastic trends in the time series variables and thus providing the possibility of the regression estimates being spurious. Henceforth emerged a separate group of earlier empirical works which began to utilize cointegration techniques, most notably the two-stage cointegration procedure of Engle and Granger (1987) and Johansen's (1991) vector error correction model (VECM), in their empirical analysis which set a trend for research output on the subject matter during the 1990's with a primary focus on industrialized economies (Bahmani-Oskooe and Sohrabian (1992), Smith (1992) and Mok (1993), Ajayi and Mougoue (1996), Ajayi et al. (1998) and Nieh and Lee (2001)). 
The Asian contagion crisis in 1998-1999 sparked a flurry of research interest concerned with examining the exchange rate-stock return nexus with specific reference to Asian economies. Prominent examples amongst this group of studies include the individual country analysis of Mishra (2004) and Ramasamy and Yeung (2005) for India; Zhao (2010) and Rutledge et al. (2014) for China as well as the panel group studies of Abdalla and Murinde (1997) for India, Korea, Pakistan and Philippines; Granger et al. (2000) for Hong Kong, Indonesia, Japan, South Korea, Malaysia, the Philippines, Singapore, Thailand and Taiwan; Smyth and Nanda (2003) for Bangladesh, India, Pakistan and Sri Lanka; Phylaktis and Ravazzolo (2005) for Hong Kong, Malaysia, Singapore, Thailand and Philippines; Yau and Nieh (2006) for Taiwan and Japan; Liu et al. (2007) for Malaysia, Singapore, Korea, Philippines, Japan, Germany and the UK; Pan et al. (2007) for Hong Kong, Japan, Korea, Malaysia, Singapore, Taiwan, Thailand; Lean et al. (2011) for Hong Kong, Indonesia, Japan, Korea, Malaysia, the Philippines, Singapore and Thailand; Lin (2012) for India, Indonesia, Korea, Philippines, Thailand and Taiwan; as well as Liang et al. $(2013,2015)$ for Indonesia, Malaysia, Philippines, Singapore and Thailand. Regardless of the extensive nature of these studies, the empirical evidence acquired from this cluster of studies, so far, can be best described as being inconclusive.

The world experienced yet another catastrophic financial crisis in September 2009, when the Lehman Brothers filed for the Chapter 11 bankruptcy protection thus leading to the US national banking crisis which propagated to global financial markets. It was following the advent of this sub-prime crisis that a majority of the empirical literature conducted for the South African economy emerged, with the study of Ocran (2010) being the earliest study to examine the exchange rate-stock price relationship for the economy. Following Ocran's (2010) study, other empirical works on the exchange rate-stock returns relationship for the South African economy began to emerge and the most prominent studies existing up-to-date include the country-specific studies of Alam et al. (2011), Mlambo et al. (2013) as well as the panel based works of Adjasi et al. (2011), Ndako (2013), Sui and Sun (2015), Fowowe (2015) and Dahir et al. (2017). Notably a majority of these previous South African studies either found no evidence of cointegration between the time series (Adjasi et al. (2011), Ndako 
(2013), Mlambo et al. (2013) and Sui and Sun (2015)) or in instances where cointegration is found, there were no causality effects (Ocran (2010), Alam et al. (2011) and Fowowe et al. (2015)).

It was also subsequent to the global financial crisis that research on the subject matter began to take a new empirical direction with economists contemplating on a possible nonlinear relationship between exchange rates and stock prices. The rationale behind this school of thought is that the relationship between exchange rates and stock prices is nonmonotonic and exchange rate exposure is different for periods of currency as compared to currency depreciation. Nonlinear studies existing in the literature up-to-date include the works of Tabak (2006) for Brazil; Kumar (2009) for India; Yau and Nieh (2009) for Japan and Taiwan; Tsai (2012) for Singapore, Thailand, Malaysia, Philippines, South Korea and Taiwan; Cakan and Ejra (2013) Turkey, Thailand, Brazil, India, Korea, Mexico, Philippines, Poland, Russia, Singapore and Taiwan; Chkili and Nguyen (2014) for Brazil, Russia, India, Chana and South Africa; Dar et al. (2014) for India, Pakistan, Bangladesh, Sri Lanka, Malaysia, Indonesia, Philippines and Thailand; Ali et. al. (2015) for South Africa; Koulakiotis et al (2015) for the US, Canada and UK; Ho and Huang (2015) for Brazil, Russia, India and China; Bahamani-Oskooee and Saha (2015) for the US; Bahamani-Oskooee and Saha (2016) for Brazil, Canada, Chile, Indonesia, Japan, Korea, Malaysia, Mexico and the UK; Cuestas and Tang (2017) for 31 Chinese industries; Bahamani-Oskooee and Saha (2017) for Argentina, Australia, Austria, Belgium, Brazil, Canada, Chile, China, France, Germany, Greece, Hong Kong, India, Indonesia, Japan, Korea, Malaysia, Mexico, Netherlands, New Zealand, Singapore, Switzerland, UK, US; and Tang (2018) for 87 Chinese auto firms.

Initially, a majority of these 'nonlinear' studies relied on MTAR cointegration framework (Yau and Nieh (2009), Ali et al. (2015), and Koulakiotis et al. (2015)), nonlinear causality tests (Tabak (2006), Kumar (2009), Cakan and Ejra (2013) and Ho and Huang (2015)) as well as quantile regressions (Tsai (2012) and Dar et al. (2014)). However, recent studies have turned to the N-ARDL model framework which provides more flexibility in 
modelling both short-run and long-run cointegration asymmetries between time series with different integration properties (i.e. Bahmani-Oskooee and Saha (2016, 2017), Cuestas and Tang (2017) and Tang (2018)). Even though these 'nonlinear studies' collectively produce different results for different economies, what is encouraging is that they commonly advocated for the exchange rate-stock price nexus as being asymmetric over the steady-state. For the sake of brevity and convenience the findings of these nonlinear studies along with the others reviewed in this section are summarized in Appendix A.

\section{EMPIRICAL FRAMEWORK}

The traditional analytical framework testing the link between stock markets and exchange rates is based on the influence of the exchange rate on firm profitability and share prices firms as modelled by Jorion (1990) and further expounded in the study of Bodnar and Gentry (1993). According to this framework, stock market returns $\left(\mathrm{smr}_{\mathrm{t}}\right)$ is modelled as being endogenous to exchange rate $\left(\mathrm{ex}_{\mathrm{t}}\right)$ :

$s m r_{t}=\beta_{0}+\beta_{1} e x_{t}+\mu_{t}$

Where $\mu_{\mathrm{t}}$ is a well-behaved error term with a zero mean and constant variance. As previously mentioned earlier studies focused on estimating equation (1) using linear cointegration models. However, nonlinear models as introduced, as firstly introduced in the seminar work of Balke and Fomby (1997) have emerged as a more appealing alternative. Nonetheless, many of the existing nonlinear cointegration models (i.e. Enders and Granger (1998), Enders and Siklos (2001), Lo and Zivot (2001) and Hansen and Seo (2002)) are too restrictive in the sense of requiring the time series to be integrated of similar order and typically focuses on short-run equilibrium asymmetries whilst ignoring crucial long-run asymmetries. Henceforth, the N-ARDL model of Shin et al. (2014) has been recently relied on in the literature to model short-run and long-run asymmetries between exchange rates and stock returns. In order to do this, we suppose that $\mathrm{EX}_{\mathrm{t}}$ can be decomposed into partial sum 
processes of positive and negative changes (i.e. $\mathrm{SR}_{\mathrm{t}}=\mathrm{EX}_{0}+E X_{t}^{+}+E X_{t}^{-}$), such that equation (1) can be re-specified as the following long-run asymmetric model:

$$
\mathrm{SR}_{\mathrm{t}}=\alpha_{0}+\beta^{+} E X_{t}^{+}+\beta^{-} E X_{t}^{-}+\mathrm{e}_{\mathrm{t}}
$$

Where $S R_{t}^{+}=\sum_{j=1}^{i} \Delta S R_{j}^{+}=\sum_{j=1}^{i} \max \left(\Delta \mathrm{SR}_{\mathrm{j}}, \quad 0\right) \quad$ and $\quad E X_{t}^{-}=\sum_{j=1}^{i} \Delta E X_{j}^{-}=$ $\sum_{j=1}^{i} \min \left(\Delta \mathrm{EX}_{\mathrm{j}}, 0\right)$. The NARDL (p, q)-in-levels transformation of regression (4) can be given as:

$$
S R_{t}=\sum_{j=1}^{p} \psi_{i} S R_{t-j}+\sum_{j=1}^{p}\left(\Phi_{j}^{+} E X_{t-j}^{+}+\Phi_{j}^{-} E X_{t-j}^{-}\right)+\zeta_{t}
$$

Whereas the associated error correction representation can be denoted as:

$$
\begin{aligned}
& S R_{t}=\sum_{j=1}^{p} \rho_{i} S R_{t-j}+\Phi_{j}^{+} E X_{t-j}^{+}+\Phi_{j}^{-} E X_{t-j}^{-}+\sum_{j=1}^{p-1} \lambda_{i} \Delta S R_{t-j}+\sum_{j=0}^{q-1}\left(\alpha_{j}^{+} \Delta E X_{t-j}^{+}+\right. \\
& \left.\alpha_{j}^{-} \Delta E X_{t-j}^{-}\right)+\zeta_{t}
\end{aligned}
$$

The asymmetric long-run parameters of interest from equations (3) and (4) are thereafter computed as $\beta^{+}=-\left(\Phi^{+} / \rho\right)$ and $\beta^{-}=-\left(\Phi^{-} / \rho\right)$. To validate the NARDL long-run and short-run effects, Shin et al. (2014) propose the testing of three empirical hypothesis. The first, is an asymmetric extension of the conventional bounds test for cointegration (Pesaran et al., 2001) and tests the null hypothesis of $\rho=\Phi^{+}=\Phi^{-}$. The second hypothesis tests the null of no long-run cointegration effects (i.e. $\beta^{-}=\beta^{+}$) whilst the third tests the null hypothesis of no short-run asymmetric effects (i.e. $\sum_{i=0}^{q-1} \alpha_{j}^{+}=\sum_{i=0}^{q-1} \alpha_{j}^{-}$).

\section{DATA AND EMPIRICAL RESULTS}

\subsection{Data description}


The empirical data used in our study is collected from the INET BFA online database and consists of five time series variables, namely, the closing values of i) the Rand-Dollar exchange rate, ii) the FTSE/JSE All Share index, iii) the FTSE/JSE Top.40 index, iv) the FTSE/JSE Industrial 25 index and v) the FTSE/JSE Resource.10 index. All utilized time series are collected over monthly frequencies for the period of January 2000 to December 2017 and we have chosen this sample period because it strictly reflects developments in the JSE which have occurred subsequent to the outfall of open outcry platforms and incorporation of fully automated trading systems. Our sampled data further coincides with an era of flexible exchange rate regime in which currency is determined by market forces without direct intervention by the Reserve Bank.

By design our dataset begins during a period when the London Stock Exchange Stock Exchange Electronic Trading System (i.e. LSE-SETS) was officially adopted as the JSE's main trading platform in 2001, just subsequent to the Asian financial crisis and Dot.com bubble burst of 1999 and 2000, respectively. In 2007, just around the advent of the filing of Chapter 11 bankruptcy by the Lehman Brother, the LSE leased yet another trading platform to the JSE i.e. JSE trade elect system, and in 2013, the JSE shifted its trading platform from London to Johannesburg under the banner of the Millennium exchange. Note that it is under this trading platform that high frequency trading was ushered into the JSE hence allowing for the speed of transactions to be executed at approximately 400 times faster than under the previous trading platforms (Phiri, 2017). Further note that our study covers all these important structural events which need to be accounted for in our empirical analysis. For empirical purposes, we transform the raw stock prices time series data into returns using the following continuous compounded returns formulae:

$R=\log \left(p_{t}\right)-\log \left(p_{t-1}\right)$

Where $\mathrm{R}$ is the compounded returns, $\mathrm{p}_{\mathrm{t}}$ is the price index and $\mathrm{p}_{\mathrm{t}-1}$ is the price index in the previous period. The time series plots of the equity returns are provided in Figure 1 whilst the summary statistics and correlation matrix are reported in Table 1 . We note that industrials 
25 has the highest average returns $(0.46 \%)$, followed by the all-share $(0.40 \%)$, top $40(0.39 \%)$ and lastly resource $10(0.25 \%)$. Conversely, resources 10 has the highest volatility (3.34), followed by top 40 (2.20), industrials 25 (2.12) and all-share (2.06). The Rand/Dollar exchange rate has generally been rising (deteriorating) from the beginning to the end of our sample period with a minimum of 10.04 ZAR/US\$ in 2001:M01 to an all-time high of 23.60 ZAR/US\$ in 2016:M01. The preliminary correlation estimates indicate that exchange rates are negatively correlated with the JSE equity returns, that is, an exchange rate appreciation (depreciation) strengthens (weakens) JSE equity returns, even though these correlations are difficult to visually ascertain from the time series plots in Figure 1. This last point may be due to the observed weak correlations identified between the exchange rate and JSE returns.

Table 2: Summary statistics and unit root tests

\begin{tabular}{cccccc}
\hline & R/DOLLAR & ALL_SHARE & TOP_40 & RES_10 & IND_25 \\
\hline Panel A: & & & & & \\
Summary & & & & & \\
statistics & & & & & \\
\cline { 1 - 2 } & 23.60 & 5.70 & 5.94 & 8.45 & 4.75 \\
Minimum & 10.04 & -6.53 & -7.01 & -11.12 & -6.64 \\
Mean & 14.14 & 0.40 & 0.39 & 0.25 & 0.46 \\
s.d. & 2.97 & 2.06 & 2.20 & 3.34 & 2.12 \\
J-B & 28.42 & 6.24 & 6.03 & 7.48 & 26.89 \\
p-value & 0.00 & 0.04 & 0.05 & 0.02 & 0.00 \\
\hline Panel B: & & & & & \\
Correlation & & & & & \\
matrix & 1 & & & & \\
\hline R/DOLLAR & -0.09 & 1 & & & \\
ALL_SHARE & -0.08 & 0.99 & 0.89 & & \\
TOP_40 & -0.11 & 0.84 & 0.86 & 1 & \\
RES_10 & -0.06 & 0.85 & 0.83 & 0.50 & 1 \\
IND_25 & & & &
\end{tabular}

Nevertheless, a number of interesting visual observations can be deduced from the individual series plots in Figure 1. For instance, the ZAR/US\$ exchange rate has been mainly affected by global distortions such as the oil price spikes of 2002-2003, the Lehman bankruptcy of 2007 as well as the second oil spikes of 2012-2014. Similarly, all JSE returns series have been influenced by the oil price hikes of $2002-2003$ as well as by the global financial crisis of 2007, although recovery from these exogenous shocks is evidently shortlives. Upon further inspection of the JSE returns series in Figure 1, we note that following the 
adoption of HFT mechanism in 2013, the series have been less volatile and, with exception of resources, the remaining series have been barely influenced by the advent of the second oil price hikes of 2012-2014. Lastly we note that for all observed time series the Jarque-Bera (JB) statistic concludes on non-normality of the variables, as is expected from the financial time series and further advocates for existing asymmetries in the time series.

Figure 1: Time series plots of variables

R/dollar

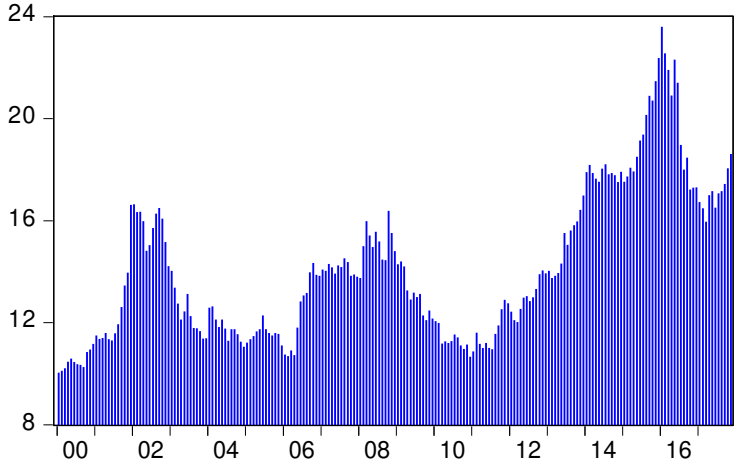

ind.25

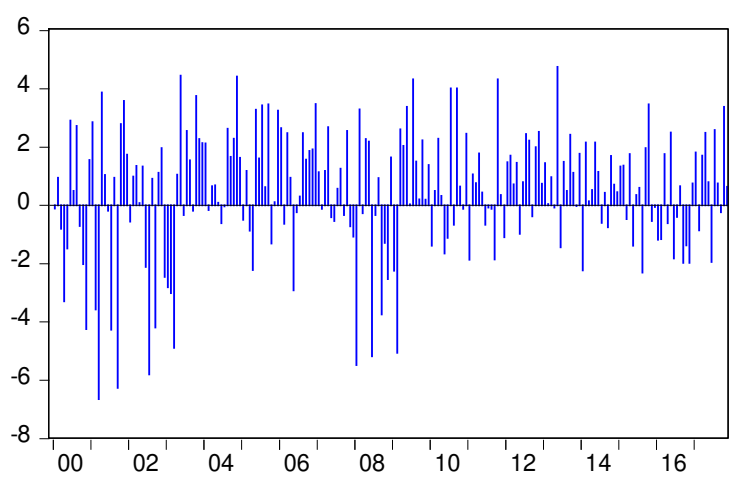

top.40

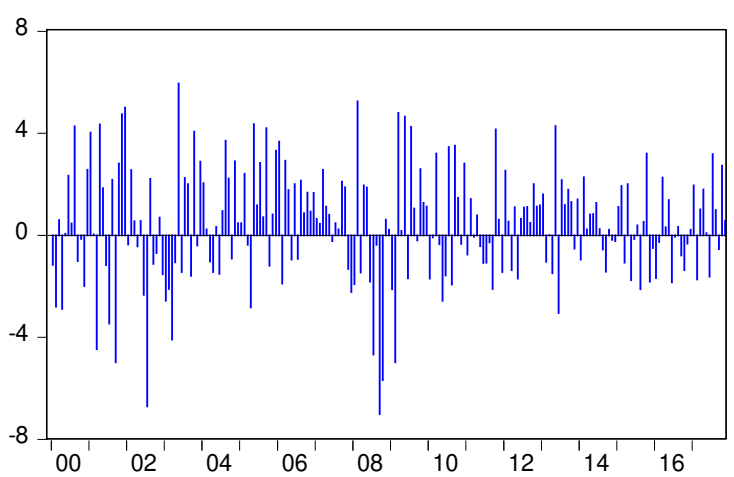

all.share

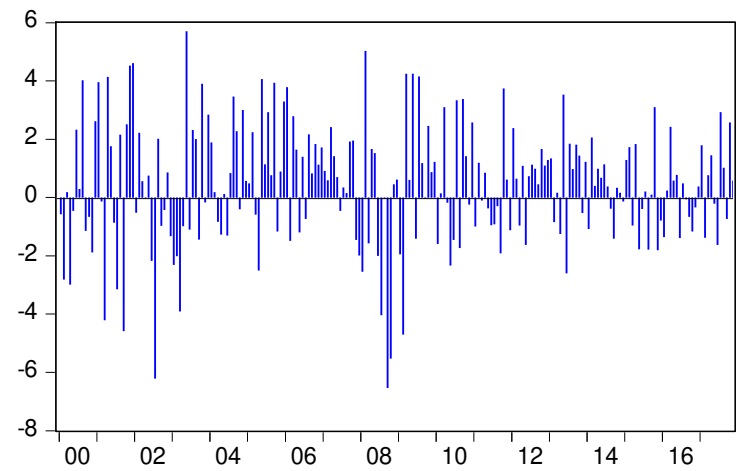

res. 10

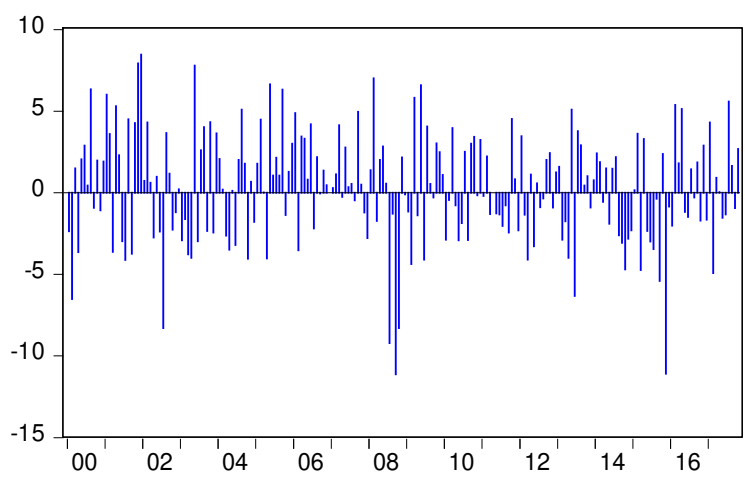


Even though the N-ARDL model does not require formal testing of unit roots within the variables, we consider it important to test the integration properties of the employed time series since the integration properties may reveal important information concerning the efficiency of the JSE. In particular, the weak-form efficient market hypothesis (EMH) insinuates that the stationarity of stock returns series reflects an efficient capital market in the sense that investors cannot obtain abnormal returns based on the historic security information as anticipated events are already integrated into the present stock price (Phiri, 2015). However, conventional unit root tests such as the ADF, PP, KPSS and DF-GLS tests ignore nonlinearity and further fail to account for important structural breaks existing within the data. Therefore, in following Kapetanois et al. (2003), we specify the following modified Dickey-Fuller unit root testing regression:

$$
\Delta \mathrm{Y}_{\mathrm{t}}=\psi_{\mathrm{i}} Y_{t-i}^{3}+\sum_{j=1}^{p} \rho_{i} \Delta Y_{t-i}+\mathrm{e}_{\mathrm{t}}
$$

Where the $\Delta$ is a first difference operator of time series $Y_{t}$, and the unit root null hypothesis is tested as $\mathrm{H}_{0}: \psi_{\mathrm{i}}=0$ using the test statistic $\left(\mathrm{DF}_{\mathrm{KSS}}\right)$ computed as:

$$
\mathrm{t}_{\mathrm{ADF}}=\frac{\widehat{\psi}}{\text { S.E. }(\widehat{\psi})}
$$

With S.E. $(\hat{\psi})$ is the standard error of the coefficient estimate $\hat{\psi}$. In order to account for structural breaks we augment the KSS regression with a flexible Fourier function (FFF) resulting the following test regression:

$$
\Delta \mathrm{Y}_{\mathrm{t}}=\delta_{\mathrm{i}} Y_{t-i}^{3}+\sum_{j=1}^{p} \rho_{i} \Delta Y_{t-i}+a_{i} \sin \left(\frac{2 \pi K t}{T}\right)+b_{i} \cos \left(\frac{2 \pi K t}{T}\right)+\mathrm{e}_{\mathrm{t}}, \quad \mathrm{t}=1,2, \ldots, \mathrm{T} .
$$

Where $\mathrm{K}$ is the singular approximated frequency selected for the approximation, whilst coefficients $\mathrm{a}$ and $\mathrm{b}$ measure the amplitude and displacement of the sinusoidal. The 
unit root null hypothesis is thus tested as $\mathrm{H}_{0}: \delta_{\mathrm{i}}=0$ which is evaluated using the following test statistic:

$\mathrm{t}_{\mathrm{KSS}-\mathrm{FF}}=\frac{\hat{\delta}}{S \cdot E \cdot(\hat{\delta})}$

Enders and Lee (2012) place emphasis on estimating a Fourier function with a singular frequency to avoid problems of over-fitting and loss of regression power. Moreover, Enders and Lee (2012) propose that regression (12) be estimated for all integer values of $\mathrm{K}$ which lie between the interval $[1,5]$ and selecting the estimation which produces the lowest sum of squared residuals (SSR). The empirical results from these testing procedures is summarized in Table 3 with Panel A reporting the results for the KSS test performed without a FFF function whilst Panel B reports the results for the test performed with a FFF function.

Table 3: KSS unit root test results with and without the FFF

\begin{tabular}{|c|c|c|c|c|c|}
\hline \multirow[t]{2}{*}{$\begin{array}{l}\text { Time } \\
\text { Series }\end{array}$} & \multicolumn{2}{|c|}{$\begin{array}{c}\text { Panel A: } \\
\text { Without FFF }\end{array}$} & \multicolumn{3}{|c|}{$\begin{array}{l}\text { Panel B: } \\
\text { With FFF }\end{array}$} \\
\hline & Lag & $t_{\mathrm{KSS}}$ & Lag & $\mathrm{K}$ & $\mathrm{t}_{\mathrm{KSS}}$ \\
\hline R/Dollar & 3 & -0.12 & 4 & 1 & $-3.01 * * *$ \\
\hline All.Share & 3 & $-2.95^{* * *}$ & 3 & 3 & $-2.79 * *$ \\
\hline Top.40 & 3 & $-2.89 * * *$ & 3 & 3 & $-3.03 * * *$ \\
\hline Ind.25 & 6 & $-4.90^{* * *}$ & 6 & 3 & $-4.92 * * *$ \\
\hline Res.10 & 3 & -1.84 & 3 & 5 & $-4.98 * * *$ \\
\hline
\end{tabular}

Judging from the empirical results reported in Table 3, we note that when the KSS unit root test is performed without a flexible Fourier function there exists evidence of a unit root in both the ZAR/USD series and the Resource 10 returns, whilst the remaining time series reject the unit root null hypothesis at all significance levels. However, when the FFF is include in the KSS testing procedure all observed time series unanimously indicate the absence of unit roots in each of the time series with the ZAR/USD, the Top.40, Industrials 25 
and the Resource 10 time series rejecting the null hypothesis at all critical levels whereas the All.Share returns reject the unit root null at a 5 percent critical level. Collectively, these results provide strong evidence that once nonlinearity and structural breaks are accounted for then the JSE is generally an efficient stock market.

\subsection{Exchange rate and stock returns around the global financial crisis}

Table 4 presents the empirical findings of the pre and post crisis eras for the AllShare, Top.40, industrial 25 and resources 10 indices. The order of our reportings systematically corresponds to the modelling procedure used in obtaining our empirical results. For instance, Panel A of Table 4 initially presents the lag selection results for all $8 \mathrm{~N}$ ARDL models using the minimal values of the AIC and SC as information criterion in determining the optimal lag for regressions. And then in the same panel, the three asymmetric cointegration tests for i) nonlinear ARDL effects ii) long-run asymmetric effects iii) short-run asymmetric effects are thereafter reported. As can be witnessed, all three forms of asymmetries are unanimously verified for all estimated regression with the sole exception of short-run asymmetric effects for the Top.40 returns in the pre-crisis period; the industrial 25 returns in the pre-crisis period; and both sub-periods for the Resource.10 returns.

Thereafter, Panel B presents the short-run and error correction estimates whilst the long-run estimates are reported in Panel $\mathrm{C}$ reports the long-run regression coefficients and for convenience sake only the normalized long-run elasticities are reported. Starting with the short-run results in Panel B, we find that a majority of the estimated short-run coefficients are positive and statistically significant at critical levels of at least 10 percent with the exception of the short-run coefficients associated with the resource sector in the post-crisis periods where the coefficients turn negative and significant. This implies that over the short-run an increase in the ZAR/USD rate (i.e. depreciation of the Rand to the Dollar) is associated with an increase in stock returns and vice versa, with the exception of the resource sector in the post-crisis period. These findings are reminiscent of the flow-oriented hypothesis of Branson (1983) and Frankel (1983) albeit for the short-run. Note that the negative and statistically 
significant error correction terms further indicate that disequilibriums in the dynamic system are corrected over the steady-state for all equity returns. Against these findings it is imperative to determine whether these short-run dynamics translate into significant long-run effects.

Concerning the long-run coefficients reported in Panel $\mathrm{C}$, we notice a switch in the sign of regression coefficients from being dominantly negative and statistically significant in the pre-crisis to being generally statistically insignificant in the post-crisis with the exception of Industrials returns. In particularly, we observe that for the pre-crisis, a percentage depreciation in the ZAR/USD rate results in a 0.29 decrease in All-Share returns whereas a percentage appreciation in the ZAR/USD rate causes a 0.40 increase in All-Share returns. Similar dynamics are observed in the post-crisis for the Industrials. 25 returns, in which a percentage appreciation in the exchange rate results in a 0.09 percentage decrease in returns whilst a percentage depreciation in exchange rate reduces returns by 0.15 percent. Notably, these nonlinear dynamics are in accordance with those found for other emerging economies as in Tang (2018) for B-share firms in China (Tang (2018)) as well as in Bahmani-Oskooee and Saha (2018) for Argentina and Malaysia.

Concerning the Top 40 returns and Industrials 25 returns in the pre-crisis an appreciation of the exchange by one percentage point reduces stock returns by -0.12 percent for Top.40 and -0.32 percent for Industrials whereas an appreciation of currency has no effect on these stock returns. These dynamics replicate those of Bahmani-Oskooee and Saha (2016) for the US and Malaysia as well as Bahmani-Oskooee and Saha (2018) for Mexico. On the other hand, we observe neither appreciations of depreciation of currency has any significant effects on stock returns in the post-crisis period for the all-share, top.40 and resource returns and this is coherent with the findings of Bahmani-Oskooee and Saha (2018) for the US and Cuestas and Tang (2017) for China. 
Table 4: Exchange rate-stock returns relationship for the pre- and post- crisis era

\begin{tabular}{|c|c|c|c|c|c|c|c|c|}
\hline & \multicolumn{2}{|c|}{ ALL_SHARE } & \multicolumn{2}{|c|}{ TOP_40 } & \multicolumn{2}{|c|}{ IND_25 } & \multicolumn{2}{|c|}{ RES_10 } \\
\hline & $\begin{array}{c}2000: 01- \\
2007: 08\end{array}$ & $\begin{array}{c}2007: 09- \\
2017: 12\end{array}$ & $\begin{array}{c}2000: 01- \\
2007: 08\end{array}$ & $\begin{array}{c}2007: 09- \\
2017: 12\end{array}$ & $\begin{array}{c}2000: 01- \\
2007: 08\end{array}$ & $\begin{array}{c}2007: 09- \\
2017: 12\end{array}$ & $\begin{array}{c}2000: 01- \\
2007: 08\end{array}$ & $\begin{array}{c}2007: 09- \\
2017: 12 \\
\end{array}$ \\
\hline $\begin{array}{c}\text { Panel A: } \\
\text { Model } \\
\text { selection and } \\
\text { Asymmetry } \\
\text { tests } \\
\end{array}$ & & & & & & & & \\
\hline $\begin{array}{c}\text { N-ARDL } \\
\text { specification }\end{array}$ & $\begin{array}{c}\text { N-ARDL } \\
(1,4,4)\end{array}$ & $\begin{array}{c}\text { N-ARDL } \\
(1,0,2)\end{array}$ & $\begin{array}{c}\text { N-ARDL } \\
(1,3,2)\end{array}$ & $\begin{array}{c}\text { N-ARDL } \\
(1,0,2)\end{array}$ & $\begin{array}{c}\text { N-ARDL } \\
(1,3,2)\end{array}$ & $\begin{array}{c}\text { N-ARDL } \\
(1,0,2)\end{array}$ & $\begin{array}{c}\text { N-ARDL } \\
(1,0,2)\end{array}$ & $\begin{array}{c}\text { N-ARDL } \\
(1,0,2)\end{array}$ \\
\hline $\begin{array}{c}\text { Bounds } \\
\text { Test }\end{array}$ & $\begin{array}{c}19.95 \\
(0.00)^{* * * *}\end{array}$ & $\begin{array}{c}52.10 \\
(0.00)^{* * *}\end{array}$ & $\begin{array}{c}84.81 \\
(0.00)^{* * * *}\end{array}$ & $\begin{array}{c}53.62 \\
(0.00)^{* * *}\end{array}$ & $\begin{array}{c}29.71 \\
(0.00)^{* * *}\end{array}$ & $\begin{array}{c}61.42 \\
(0.00)^{* * *}\end{array}$ & $\begin{array}{c}41.24 \\
(0.00)^{* * *}\end{array}$ & $\begin{array}{c}13.39 \\
(0.00)^{* * *}\end{array}$ \\
\hline $\begin{array}{l}\text { Long-run } \\
\text { asymmetry }\end{array}$ & $\begin{array}{c}3.69 \\
(0.00)^{* * * *}\end{array}$ & $\begin{array}{c}2.54 \\
(0.01)^{* *}\end{array}$ & $\begin{array}{c}2.89 \\
(0.00)^{* * * *}\end{array}$ & $\begin{array}{c}2.55 \\
(0.01)^{* *}\end{array}$ & $\begin{array}{c}3.52 \\
(0.00)^{* * *}\end{array}$ & $\begin{array}{c}4.17 \\
(0.00)^{* * *}\end{array}$ & $\begin{array}{c}3.62 \\
(0.06)^{*}\end{array}$ & $\begin{array}{c}0.64 \\
(0.42)\end{array}$ \\
\hline $\begin{array}{l}\text { Short-run } \\
\text { asymmetry }\end{array}$ & $\begin{array}{c}11.72 \\
(0.00)^{* * *}\end{array}$ & $\begin{array}{c}2.73 \\
(0.00)^{* * *}\end{array}$ & $\begin{array}{c}1.05 \\
(0.30)\end{array}$ & $\begin{array}{c}2.71 \\
(0.00)^{* * *}\end{array}$ & $\begin{array}{c}0.04 \\
(0.85)\end{array}$ & $\begin{array}{c}2.96 \\
(0.00)^{* * *}\end{array}$ & $\begin{array}{c}0.07 \\
(0.79)\end{array}$ & $\begin{array}{c}3.28 \\
(0.04)^{*}\end{array}$ \\
\hline $\begin{array}{l}\text { Panel B: } \\
\text { Short-run } \\
\text { estimates }\end{array}$ & & & & & & & & \\
\hline$\Delta s r_{t-1}$ & $\begin{array}{c}1.85 \\
(0.08)^{*}\end{array}$ & & & & & & & $\begin{array}{c}-0.22 \\
(0.01)^{* *}\end{array}$ \\
\hline$\Delta e x^{+}$ & $\begin{array}{c}1.03 \\
(0.12)\end{array}$ & & & & & & $\begin{array}{c}2.73 \\
(0.00)^{* * *}\end{array}$ & \\
\hline$\Delta e x^{-}$ & $\begin{array}{l}-1.21 \\
(0.28)\end{array}$ & & & & & & & $\begin{array}{c}-1.74 \\
(0.05)^{*}\end{array}$ \\
\hline$\Delta e x_{t-1}^{+}$ & $\begin{array}{c}0.54 \\
(0.45)\end{array}$ & & & & & & & \\
\hline$\Delta e x_{t-2}^{+}$ & $\begin{array}{c}0.76 \\
(0.29)\end{array}$ & & & & & & & \\
\hline$\Delta e x_{t-3}^{+}$ & $\begin{array}{c}1.17 \\
(0.10)\end{array}$ & & $\begin{array}{c}0.80 \\
(0.05)^{*}\end{array}$ & & $\begin{array}{c}1.47 \\
(0.03)^{* *}\end{array}$ & & & \\
\hline$\Delta e x_{t-4}^{+}$ & $\begin{array}{c}0.99 \\
(0.18)\end{array}$ & & & & & & & \\
\hline$\Delta e x_{t-2}^{-}$ & $\begin{array}{c}1.85 \\
(0.08)^{*}\end{array}$ & $\begin{array}{c}1.32 \\
(0.00)^{* * * *}\end{array}$ & $\begin{array}{c}1.44 \\
(0.00)^{* * *}\end{array}$ & $\begin{array}{c}1.41 \\
(0.00)^{* * *}\end{array}$ & $\begin{array}{c}1.72 \\
(0.08)^{*}\end{array}$ & $\begin{array}{c}1.38 \\
(0.00)^{* * *}\end{array}$ & $\begin{array}{c}3.12 \\
(0.02)^{* *}\end{array}$ & $\begin{array}{c}1.39 \\
(0.10)\end{array}$ \\
\hline$\Delta e x_{t-3}^{-}$ & $\begin{array}{l}-0.76 \\
(0.50)\end{array}$ & & & & & & & \\
\hline$\Delta e x_{t-4}^{-}$ & $\begin{array}{c}1.00 \\
(0.35)\end{array}$ & & & & & & & \\
\hline ect $t_{t-1}$ & $\begin{array}{c}-0.89 \\
(0.00)^{* * *}\end{array}$ & $\begin{array}{c}-0.18 \\
(0.00)^{* * *}\end{array}$ & $\begin{array}{c}-0.84 \\
(0.00)^{* * *}\end{array}$ & $\begin{array}{c}-0.41 \\
(0.00)^{* * *}\end{array}$ & $\begin{array}{c}-0.35 \\
(0.02)^{* *}\end{array}$ & $\begin{array}{c}-0.24 \\
(0.00)^{* * *}\end{array}$ & $\begin{array}{c}-0.51 \\
(0.01)^{* *}\end{array}$ & $\begin{array}{c}-0.32 \\
(0.00)^{* * *}\end{array}$ \\
\hline $\begin{array}{c}\text { Panel C: } \\
\text { Asymmetric } \\
\text { long run } \\
\text { elasticities }\end{array}$ & & & & & & & & \\
\hline$\beta_{e x}^{+}$ & $\begin{array}{c}-0.29 \\
(0.04)^{*}\end{array}$ & $\begin{array}{l}-0.05 \\
(0.27)\end{array}$ & $\begin{array}{l}-0.08 \\
(0.16)\end{array}$ & $\begin{array}{l}-0.07 \\
(0.24)\end{array}$ & $\begin{array}{l}-0.18 \\
(0.14)\end{array}$ & $\begin{array}{c}-0.09 \\
(0.05)^{*}\end{array}$ & $\begin{array}{l}-0.01 \\
(0.98)\end{array}$ & $\begin{array}{l}-0.14 \\
(0.28)\end{array}$ \\
\hline$\beta_{e x}^{-}$ & $\begin{array}{c}-0.40 \\
(0.01)^{* *}\end{array}$ & $\begin{array}{c}0.09 \\
(0.17)\end{array}$ & $\begin{array}{c}-0.12 \\
(0.08)^{*}\end{array}$ & $\begin{array}{c}0.10 \\
(0.15)\end{array}$ & $\begin{array}{c}-0.32 \\
(0.03)^{* *}\end{array}$ & $\begin{array}{c}-0.15 \\
(0.01)^{* *}\end{array}$ & $\begin{array}{l}-0.09 \\
(0.58)\end{array}$ & $\begin{array}{l}-0.17 \\
(0.29)\end{array}$ \\
\hline $\begin{array}{c}\text { Panel D: } \\
\text { Diagnostic } \\
\text { tests }\end{array}$ & & & & & & & & \\
\hline J-B & $\begin{array}{c}0.28 \\
(0.87)\end{array}$ & $\begin{array}{c}0.08 \\
(0.92)\end{array}$ & $\begin{array}{c}0.95 \\
(0.55)\end{array}$ & $\begin{array}{c}0.27 \\
(0.67)\end{array}$ & $\begin{array}{c}0.63 \\
(0.56)\end{array}$ & $\begin{array}{c}0.47 \\
(0.62)\end{array}$ & $\begin{array}{c}0.72 \\
(0.69)\end{array}$ & $\begin{array}{c}3.14 \\
(0.20)\end{array}$ \\
\hline B-G & $\begin{array}{c}0.29 \\
(0.74)\end{array}$ & $\begin{array}{c}0.61 \\
(0.54)\end{array}$ & $\begin{array}{c}0.40 \\
(0.67)\end{array}$ & $\begin{array}{c}0.67 \\
(0.51)\end{array}$ & $\begin{array}{c}1.08 \\
(0.34)\end{array}$ & $\begin{array}{c}1.28 \\
(0.28)\end{array}$ & $\begin{array}{c}0.31 \\
(0.73)\end{array}$ & $\begin{array}{c}0.21 \\
(0.81)\end{array}$ \\
\hline B-P-G & $\begin{array}{c}1.25 \\
(0.26)\end{array}$ & $\begin{array}{c}0.58 \\
(0.61)\end{array}$ & $\begin{array}{c}0.08 \\
(0.93)\end{array}$ & $\begin{array}{c}0.46 \\
(0.69)\end{array}$ & $\begin{array}{c}0.26 \\
(0.76)\end{array}$ & $\begin{array}{c}1.17 \\
(0.16)\end{array}$ & $\begin{array}{c}0.14 \\
(0.94)\end{array}$ & $\begin{array}{c}0.95 \\
(0.29)\end{array}$ \\
\hline RESET & $\begin{array}{c}1.16 \\
(0.25)\end{array}$ & $\begin{array}{c}0.87 \\
(0.39)\end{array}$ & $\begin{array}{c}1.55 \\
(0.12)\end{array}$ & $\begin{array}{c}0.98 \\
(0.33)\end{array}$ & $\begin{array}{c}1.60 \\
(0.12)\end{array}$ & $\begin{array}{c}0.62 \\
(0.53)\end{array}$ & $\begin{array}{c}1.42 \\
(0.16)\end{array}$ & $\begin{array}{c}1.01 \\
(0.32)\end{array}$ \\
\hline
\end{tabular}

Note: “***”, “***, “*” represent the $1 \%, 5 \%$ and $10 \%$ significance levels, respectively. J-B is the Jarque Bera tests for normality, B-G is the

Breusch-Godfrey test for serial correlation; the B-P-G is Breusch-Pagan-Godfrey test for hetereoskedasticity and Ramsey's RESET test for 
function form and indicate that errors from all estimate regressions are normal, homoscedastic are free from autocorrelation as well as the regressions being of correct function form.

\subsection{Exchange rate and stock returns around the adoption of a new trading platform}

Having validated the proposition that the exchange rate-stock returns relationship has changed from being generally significant in the pre-crisis period to being absent in the postcrisis period, we now examine whether the adoption of the Millennium trading platform has altered this relationship in the post-crisis periods. To this end, we provide the N-ARDL estimates corresponding to the pre- Millennium periods and post- Millennium periods for all equity returns which are reported in Table 5. Once again Panel A reports the selected NARDL specifications based on the AIC and SC information criterion which are accompanied by their respective tests for asymmetric ARDL effects, long-run asymmetries and short-run asymmetries. The findings indicate that all regressions reject the three null hypotheses of no $\mathrm{N}$-ARDL effects, no-long-run asymmetries and no short-run asymmetries for all stock returns in both sub-periods with the sole exception of the Resource.10 returns in which the null hypothesis of 'no long-run asymmetries' cannot be rejected in both sub-periods.

Panel B of Table 4 then reports the short-run and error correction dynamics. In differing from the previous results we obtain more negative and significant short-run coefficient estimates within these periods hence advocating for flow-oriented model of Dornbusch and Fischer (1980) and Gavin (1989) over the short-run. Nevertheless, the error correction terms produce the correct and statistically significant coefficients which implies convergence to the equilibrium after a shock to the system. In turning to our long-run elasticities reported in Panel C, we observe negative and statistically significant estimates for All-Share, Top.40 and Industrials. 25 and during the post-Millennium era whereas during the pre-Millennium period, the elasticities are all negative yet insignificant for all equity returns. In particular, we find that during the post-Millennium period a percentage depreciation in the ZAR/US rate results in 0.13 decrease in All-Share returns and a 0.14 increase in the Top.40 returns whereas a percentage appreciation in the exchange rate causes a 0.18 percentage 
increase in the All-Share returns, a 0.20 percentage decrease in the Top.40 returns and a 0.13 percentage decrease in Industrials.25 returns. Note that all coefficient estimates for Resource.10 returns are insignificant in both sub-samples periods and this finding is unsurprising since previously we were unable to reject the null hypothesis of no asymmetric long-run effects for the Resource.10 returns.

Table 5: Exchange rate-stock returns relationship for the pre- and post-Millennium era

\begin{tabular}{|c|c|c|c|c|c|c|c|c|}
\hline & \multicolumn{2}{|c|}{ ALL_SHARE } & \multicolumn{2}{|c|}{ TOP_40 } & \multicolumn{2}{|c|}{ IND_25 } & \multicolumn{2}{|c|}{ RES_10 } \\
\hline & $\begin{array}{c}\text { 2007:09 - } \\
\text { 2012:07 }\end{array}$ & $\begin{array}{c}\text { 2012:07 - } \\
\text { 2017:12 }\end{array}$ & $\begin{array}{c}\text { 2007:09 - } \\
\text { 2012:07 }\end{array}$ & $\begin{array}{l}\text { 2012:07 - } \\
\text { 2017:12 }\end{array}$ & $\begin{array}{c}\text { 2007:09 - } \\
\text { 2012:07 }\end{array}$ & $\begin{array}{c}\text { 2012:07 - } \\
\text { 2017:12 }\end{array}$ & $\begin{array}{c}\text { 2007:09 - } \\
\text { 2012:07 }\end{array}$ & $\begin{array}{r}2012: 07- \\
2017: 12 \\
\end{array}$ \\
\hline $\begin{array}{c}\text { Panel A: } \\
\text { Model selection } \\
\text { and Asymmetry } \\
\text { tests }\end{array}$ & & & & & & & & \\
\hline $\begin{array}{c}\text { N-ARDL } \\
\text { specification }\end{array}$ & $\begin{array}{c}\text { N-ARDL } \\
(1,4,2)\end{array}$ & $\begin{array}{c}\text { N-ARDL } \\
(1,4,4)\end{array}$ & $\begin{array}{c}\text { N-ARDL } \\
(1,4,2)\end{array}$ & $\begin{array}{c}\text { N-ARDL } \\
(1,4,4)\end{array}$ & $\begin{array}{c}\text { N-ARDL } \\
(1,4,2)\end{array}$ & $\begin{array}{c}\text { N-ARDL } \\
(1,4,4)\end{array}$ & $\begin{array}{c}\text { N-ARDL } \\
(1,4,2)\end{array}$ & $\begin{array}{l}\text { N-ARDL } \\
(1,4,1)\end{array}$ \\
\hline $\begin{array}{c}\text { Bounds } \\
\text { Test }\end{array}$ & $\begin{array}{c}10.64 \\
(0.00)^{* * *}\end{array}$ & $\begin{array}{c}45.78 \\
(0.00)^{* * *}\end{array}$ & $\begin{array}{c}15.12 \\
(0.00)^{* * *}\end{array}$ & $\begin{array}{c}48.77 \\
(0.00)^{* * *}\end{array}$ & $\begin{array}{c}40.81 \\
(0.00)^{* * *}\end{array}$ & $\begin{array}{c}54.20 \\
(0.00)^{* * *}\end{array}$ & $\begin{array}{c}10.68 \\
(0.00)^{* * *}\end{array}$ & $\begin{array}{c}6.67 \\
(0.00)^{* * *}\end{array}$ \\
\hline $\begin{array}{l}\text { Long-run } \\
\text { asymmetry }\end{array}$ & $\begin{array}{c}2.31 \\
(0.02)^{* *}\end{array}$ & $\begin{array}{c}3.30 \\
(0.00)^{* * *}\end{array}$ & $\begin{array}{c}2.05 \\
(0.04)^{*}\end{array}$ & $\begin{array}{c}3.62 \\
(0.00)^{* * *}\end{array}$ & $\begin{array}{c}3.91 \\
(0.00)^{* * *}\end{array}$ & $\begin{array}{c}3.86 \\
(0.00)^{* * *}\end{array}$ & $\begin{array}{c}0.99 \\
(0.32)\end{array}$ & $\begin{array}{c}0.28 \\
(0.60)\end{array}$ \\
\hline $\begin{array}{c}\text { Short-run } \\
\text { asymmetry }\end{array}$ & $\begin{array}{c}8.50 \\
(0.00)^{* * *}\end{array}$ & $\begin{array}{c}4.39 \\
(0.00)^{* * * *}\end{array}$ & $\begin{array}{c}11.34 \\
(0.00)^{* * *}\end{array}$ & $\begin{array}{c}4.70 \\
(0.00)^{* * *}\end{array}$ & $\begin{array}{c}19.54 \\
(0.00)^{* * *}\end{array}$ & $\begin{array}{c}7.48 \\
(0.00)^{* * *}\end{array}$ & $\begin{array}{c}5.96 \\
(0.00)^{* * * *}\end{array}$ & $\begin{array}{c}3.19 \\
(0.05)^{*}\end{array}$ \\
\hline $\begin{array}{l}\text { Panel B: } \\
\text { Short-run } \\
\text { estimates }\end{array}$ & & & & & & & & \\
\hline$\Delta s r_{t-1}$ & $\begin{array}{c}-0.22 \\
(0.05)^{*}\end{array}$ & & $\begin{array}{c}-0.22 \\
(0.05)^{*}\end{array}$ & & & $\begin{array}{c}-0.11 \\
(0.12)^{* * *}\end{array}$ & $\begin{array}{l}-2.69 \\
(0.11)\end{array}$ & $\begin{array}{c}-0.35 \\
(0.00)^{* * *}\end{array}$ \\
\hline$\Delta e x^{+}$ & & $\begin{array}{c}-1.13 \\
(0.00)^{* * *}\end{array}$ & & & & & & \\
\hline$\Delta e x^{-}$ & $\begin{array}{c}-1.78 \\
(0.09)^{*}\end{array}$ & & & $\begin{array}{c}-0.95 \\
(0.04)^{*}\end{array}$ & & & & \\
\hline$\Delta e x_{t-2}^{+}$ & & & & & & $\begin{array}{c}-1.38 \\
(0.01)^{* *}\end{array}$ & & $\begin{array}{c}2.20 \\
(0.06)^{*}\end{array}$ \\
\hline$\Delta e x_{t-3}^{+}$ & & $\begin{array}{c}0.77 \\
(0.07)^{*}\end{array}$ & & & & & & \\
\hline$\Delta e x_{t-4}^{+}$ & $\begin{array}{c}-2.14 \\
(0.00)^{* * *}\end{array}$ & $\begin{array}{c}1.31 \\
(0.01)^{* *}\end{array}$ & $\begin{array}{c}-2.22 \\
(0.00)^{* * *}\end{array}$ & $\begin{array}{c}1.17 \\
(0.04)^{*}\end{array}$ & $\begin{array}{c}-2.21 \\
(0.00)^{* * *}\end{array}$ & $\begin{array}{c}0.89 \\
(0.12)\end{array}$ & $\begin{array}{c}-2.69 \\
(0.03)^{* *}\end{array}$ & \\
\hline$\Delta e x_{t-1}^{-}$ & & & & $\begin{array}{c}-0.76 \\
(0.08)^{*}\end{array}$ & & & & $\begin{array}{l}-1.55 \\
(0.11)\end{array}$ \\
\hline$\Delta e x_{t-2}^{-}$ & $\begin{array}{c}2.66 \\
(0.00)^{* * * *}\end{array}$ & $\begin{array}{c}0.83 \\
(0.04)^{*}\end{array}$ & $\begin{array}{c}2.91 \\
(0.00)^{* * *}\end{array}$ & $\begin{array}{c}0.94 \\
(0.03)^{* *}\end{array}$ & $\begin{array}{c}2.18 \\
(0.02)^{* *}\end{array}$ & $\begin{array}{c}1.35 \\
(0.00)^{* * * *}\end{array}$ & $\begin{array}{c}3.17 \\
(0.05)^{*}\end{array}$ & \\
\hline$\Delta e x_{t-4}^{-}$ & & $\begin{array}{c}0.68 \\
(0.11)\end{array}$ & & $\begin{array}{c}1.18 \\
(0.02)^{* *}\end{array}$ & & $\begin{array}{c}1.34 \\
(0.00)^{* * * *}\end{array}$ & & \\
\hline$e^{e c t} t_{t-1}$ & $\begin{array}{l}-0.18 \\
(0.00)\end{array}$ & $\begin{array}{c}-0.21 \\
(0.00)^{* * *}\end{array}$ & $\begin{array}{c}-0.08 \\
(0.00)^{* * *}\end{array}$ & $\begin{array}{c}-0.13 \\
(0.00)^{* * *}\end{array}$ & $\begin{array}{c}-0.15 \\
(0.00)^{* * *}\end{array}$ & $\begin{array}{c}-0.24 \\
(0.00)^{* * *}\end{array}$ & $\begin{array}{c}-0.09 \\
(0.00)^{* * *}\end{array}$ & $\begin{array}{c}-0.16 \\
(0.00)^{* * *}\end{array}$ \\
\hline $\begin{array}{c}\text { Panel C: } \\
\text { Asymmetric } \\
\text { long run } \\
\text { elasticities } \\
\end{array}$ & & & & & & & & \\
\hline$\beta_{e x}^{+}$ & $\begin{array}{c}0.09 \\
(0.63)\end{array}$ & $\begin{array}{c}-0.13 \\
(0.01)^{* *}\end{array}$ & $\begin{array}{c}0.10 \\
(0.50)\end{array}$ & $\begin{array}{c}0.14 \\
(0.01)^{* *}\end{array}$ & $\begin{array}{l}-0.03 \\
(0.76)\end{array}$ & $\begin{array}{c}0.08 \\
(0.18)\end{array}$ & $\begin{array}{c}0.12 \\
(0.66)\end{array}$ & $\begin{array}{l}-0.28 \\
(0.20)\end{array}$ \\
\hline$\beta_{e x}^{-}$ & $\begin{array}{c}0.14 \\
(0.48)\end{array}$ & $\begin{array}{c}-0.18 \\
(0.01)^{* *}\end{array}$ & $\begin{array}{c}0.06 \\
(0.75)\end{array}$ & $\begin{array}{c}0.20 \\
(0.00)^{* * *}\end{array}$ & $\begin{array}{l}-0.09 \\
(0.44)\end{array}$ & $\begin{array}{c}0.13 \\
(0 . .06)^{*}\end{array}$ & $\begin{array}{c}0.08 \\
(0.79)\end{array}$ & $\begin{array}{l}-0.31 \\
(0.26)\end{array}$ \\
\hline $\begin{array}{c}\text { Panel D: } \\
\text { Diagnostic tests }\end{array}$ & & & & & & & & \\
\hline $\mathrm{J}-\mathrm{B}$ & $\begin{array}{c}0.82 \\
(0.66)\end{array}$ & $\begin{array}{c}0.04 \\
(0.98)\end{array}$ & $\begin{array}{c}0.82 \\
(0.66)\end{array}$ & $\begin{array}{c}0.16 \\
(0.92)\end{array}$ & $\begin{array}{c}0.84 \\
(0.26)\end{array}$ & $\begin{array}{c}0.70 \\
(0.71)\end{array}$ & $\begin{array}{c}0.42 \\
(0.80)\end{array}$ & $\begin{array}{c}1.14 \\
(0.56)\end{array}$ \\
\hline
\end{tabular}




\begin{tabular}{|c|c|c|c|c|c|c|c|c|}
\hline \multirow[t]{2}{*}{ B-G } & 0.14 & 0.68 & 0.01 & 1.76 & 0.69 & 1.74 & 0.84 & 1.13 \\
\hline & $(0.87)$ & $(0.38)$ & $(0.98)$ & (0.18) & $(0.51)$ & (0.19) & $(0.44)$ & (0.33) \\
\hline \multirow[t]{2}{*}{ B-P-G } & 0.32 & 1.16 & 0.87 & 0.75 & 1.31 & 0.66 & 0.84 & 0.99 \\
\hline & $(0.63)$ & $(0.35)$ & $(0.40)$ & $(0.65)$ & $(0.27)$ & $(0.72)$ & $(0.46)$ & $(0.44)$ \\
\hline \multirow[t]{2}{*}{ RESET } & 0.81 & 1.02 & 1.07 & 0.83 & 0.75 & 0.84 & 0.27 & 0.86 \\
\hline & $(0.42)$ & $(0.31)$ & $(0.29)$ & $(0.41)$ & $(0.46)$ & $(0.41)$ & (0.79) & $(0.40)$ \\
\hline
\end{tabular}

$10 \%$ significance levels, respectively. J-B is the Jarque Bera tests for normality, B-G is the Breusch-Godfrey test for serial correlation; the B-P-G is Breusch-Pagan-Godfrey test for hetereoskedasticity and Ramsey's RESET test for function form and indicate that errors from all estimate regressions are normal, homoscedastic are free from autocorrelation as well as the regressions being of correct function form.

\section{SENSITIVITY ANALYSIS}

As part of the study's sensitivity analysis, we model panel N-ARDL regression to the 4 classes of equity returns and determine whether there are possible aggregation biases in the exchange rate-stock returns relationship for South Africa. To this end, we estimate the panel $\mathrm{N}$-ARDL models for 4 sub-sample periods corresponding to the pre-crisis period, the postcrisis period, the pre-Millennium period and the post-Millennium period and report the results in Table 6. Panel A of Table 6 shows the lag selection for the different panel regressions and also shows that all panel regressions reject the null hypotheses of no asymmetric ARDL effects, no long-run asymmetries and no short-run asymmetries with the exception of the panel associated with the pre-Millennium period which fails to reject the null of no long-run asymmetries.

Note that form Panel B of Table 6, the short-run effects in all sub-samples are more pronounced in terms of significance even though the signs on the coeffecints vary from one sector to another. Nevertheless, all produced error correction terms are correctly negative and significant hence vouching for equilibrium convergence for all equity returns. In turning to the long-run elasticities reported in Panel C, we notice significant estimates for the pre-crisis and pre-Millennium periods only. We particularly find negative and statistically significant estimates

on both

$\beta_{e x}^{+}$

and $\beta_{\text {ex }}^{-}$coefficients in the pre-crisis, a result which loosely mimics that previously obtained for the All-Share returns and to a lesser extent for the Top.40 and Industrial.25 series. Conversely, for the pre-Millennium period we find positive and statistically significant values 
$\beta_{\text {ex }}^{-}$coefficients, a finding which runs contrary to the positive and insignificant values previously obtained for the individual equity returns series.

We also obtain insignificant long-run elasticities in our panel estimates for periods corresponding to the post-crisis era and the post-Millennium era. The insignificant long-run coefficients found for the post-crisis periods have been previously established for all the individual equity returns whilst the insignificant long-run elasticities found for the postMillennium period appear to be biased towards the Resource.10 equity returns. Therefore we conclude on a certain degree of biasedness observed with the panel aggregated approach, especially for periods corresponding to the post-Millennium period.

Table 6: Panel N-ARDL estimates of exchange rate-stock returns relationship

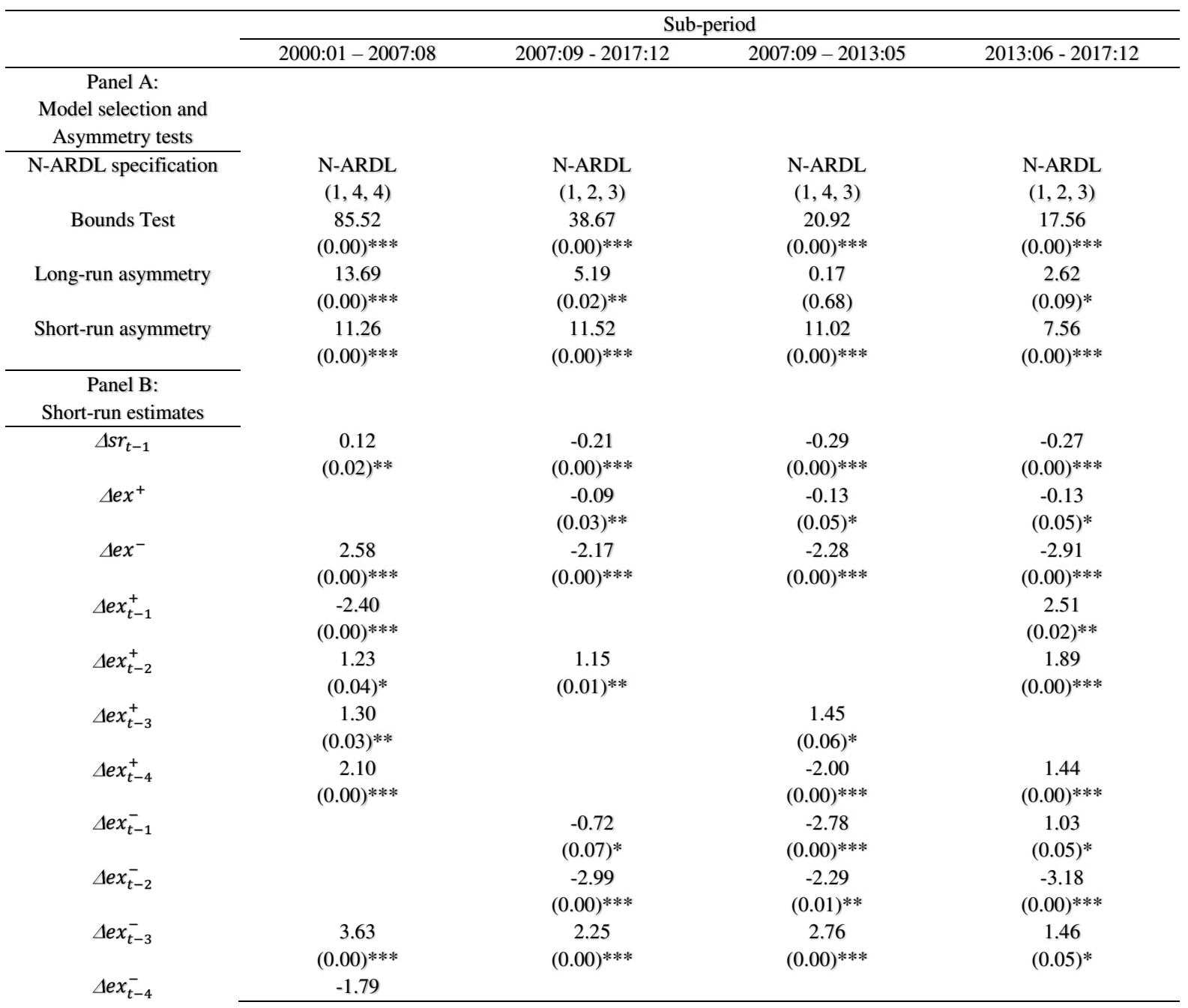




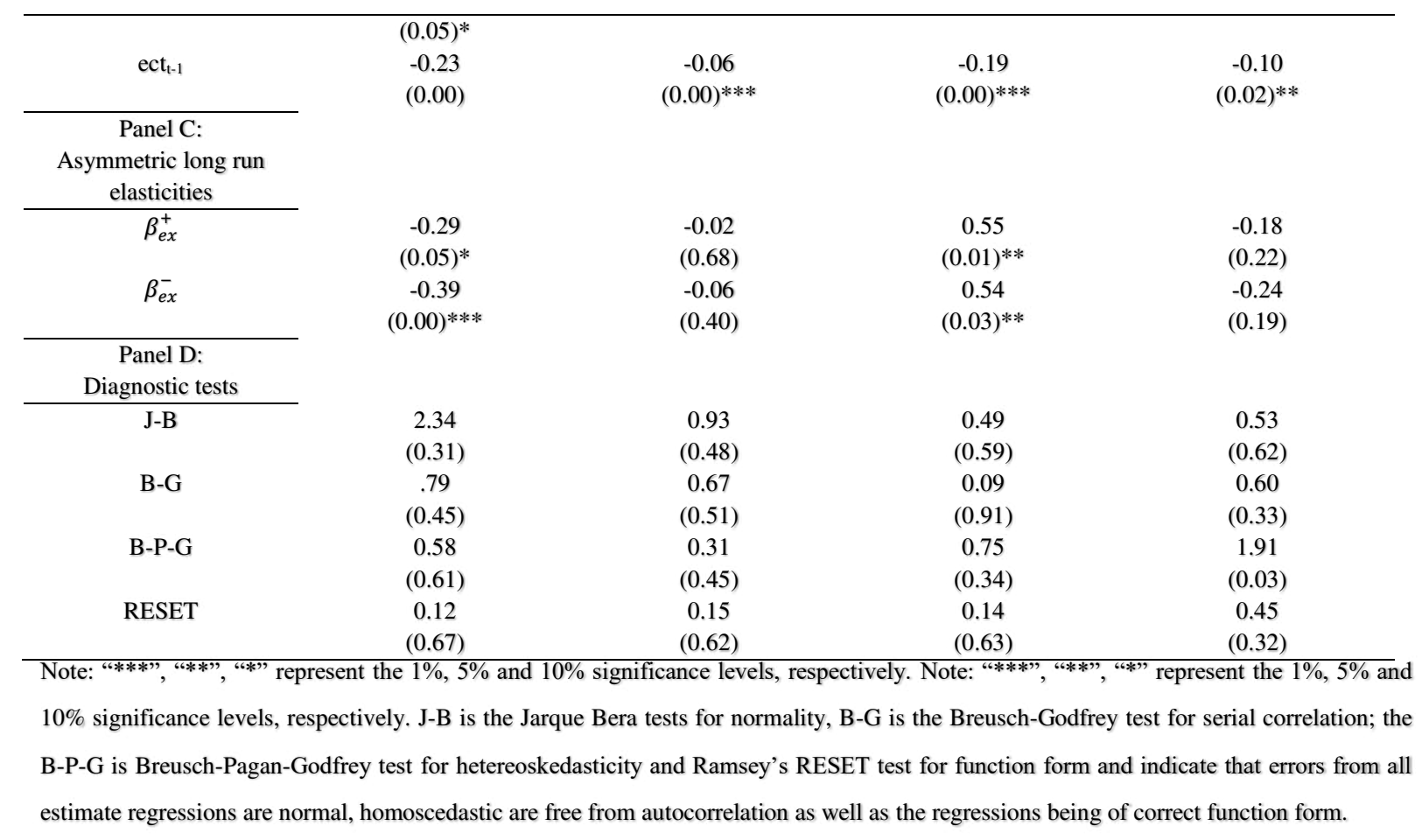

\section{CONCLUSIONS}

Through its contagion effects, the adverse effects of the 2007 global financial crisis were initially reflected on the South African economy though deteriorated JSE equity stock returns and yet the adoption of Millennium trading platform may have resuscitated the JSE through increased trade volume and decreased volatility in stock returns. The paper investigates the effects of the Rand/Dollar exchange rate on JSE sectoral returns in light of the crisis and the new trading platforms. By utilizing the nonlinear autoregressive distributive lag model applied to monthly data spanning from 2000:M01 to 2017:M12, the study is able to demonstrate the asymmetric change in the exchange rate-stock returns dynamics across the different sub periods corresponding to the two structural events.

Based on our findings we report that prior to the crisis, currency appreciation led to increases in stock returns whereas currency depreciations only decrease equity returns for the Top.40 sector. The results obtained for the entire post crisis period fail to establish any significant long-run relationship between currency movements and sectoral returns. However, upon further segregating the post-crisis data into periods corresponding to the pre and post 
'Millennium' trading eras, we observe that the absence of a long-run exchange rate-stock returns relationship is only found during the pre-Millennium era whereas during the postMillennium era the relationship re-emerges albeit varying between different classes of equity returns.

In summing up our paper, this paper provides fresh evidence which identifies the adoption of the Millennium trading platform as creating a significant change in exchange rate-stock market dynamics since the sub-prime crisis. Nevertheless, there has been concern that high frequency trading as ushered in by the Millennium exchange destabilizes the markets through predator trading. In light of the possibility of high frequency traders using the exchange rate to predict stock returns, our paper thus calls for increased structural reforms in the stock markets through improved regulatory structures.

\section{REFERENCES}

Abdalla and Murinde V. (1997), "Exchange rate and stock price interactions in emerging financial markets: Evidence on India, Korea, Pakistan and Philippines", Applied Financial Economics, 7(1), 25-35.

Adjasi C., Biekpe N. and Osei K. (2011), "Stock prices and exchange rate dynamics in selected African countries: A bivariate analysis", African Journal of Economic and Management Sciences, 2(2), 143-164.

Aggarwal R. (1981), "Exchange rates and stock prices: A study of the US capital markets under floating exchange rates", Akron Business and Economic Review, 12, 7-12.

Ajayi R. and Mougoue M. (1996), “On the dynamic relation between stock prices and exchange rates", The Journal of Financial Research, 19(2), 193-207. 
Ajayi R., Friedman J. and Mehdian S. (1998), “On the relationship between stock returns and exchange rates: Tests of granger causality", Global Finance Journal, 19(2), 241-251.

Alam M., Uddin M. and Taufique R. (2001), "The relationships between exchange rates and stock prices: Empirical investigation from Johannesburg Stock Exchange", Inventi Rapid: Emerging Economies, 2011(3), 0-8.

Ali H., Mukhtar U. and Maniam G (2015), "Dynamic links between exchange rates and stock prices in Malaysia: An asymmetric cointegration analysis", Journal of Economics and Political Economy, 2(3), 411-417.

Ali H., Idris M. and Kofarmata Y. (2015), "Stock prices and exchange rates dynamics in South Africa: An application of asymmetric co-integration approach", Journal of Economics Library, 2(3), 165-173.

Amare T. and Mohsin M. (2000), "Stock prices and exchange rates in the leading Asian economies: Short versus long-run dynamics”, Singapore Economic Review, 45(2), 165-181.

Ang J. and Ghallab A. (1976), "The impact of U.S. devaluations on the stock prices of multinational corporations", Journal of Business Research, 4(1), 25-34.

Bahmani-Oskooe M. and Sohrabian A. (1992), "Stock prices and the effective exchange rate of the dollar", Applied Economics, 24(4), 459-464.

Bahmani-Oskooe M. and Saha S. (2015), "On the relation between stock prices and exchange rates: A review article", Journal of Economic Studies, 42(4), 707-732.

Bahmani-Oskooe M. and Saha S. (2016), "Do exchange rates have symmetric or asymmetric effects on stock prices?", Global Finance Journal, 31, 57-72. 
Bahmani-Oskooe M. and Saha S. (2018), “On the relation between exchange rates and stock prices: A non-linear ARDL approach and asymmetry analysis", Journal of Economics and Finances, 42(1), 112-137.

Balke N. and Fomby T. (1997), “Threshold cointegration”, International Economic Review, $38,627-645$.

Bodnar G. and Gentry W. (1993), "Exchange rate exposure and industry characteristics: Evidence from Canada, Japan and the USA", Journal of International Money and Finance, $12,29-45$

Branson W. (1983), "Macroeconomic determinants of real exchange risk", NBER Working Paper No. 801, Novermber.

Cakan E. and Ejra D. (2013), "On the relationship between exchange rates and stock prices: Evidence from emerging markets", International Research Journal of Finance and Economics, 111, 115-124.

Chkili W. and Nguyen D. (2014), "Exchange rate movements and stock market returns in a regime-switching environment: Evidence from BRICS countries", Research in International Business and Finance, 31, 45-56.

Cuestas And Tang (2017), “Asymmetric exchange rate exposure of stock returns: Empirical evidence from Chinese industries", Studies in Nonlinear Dynamics and Econometrics, 21(4), $1-21$.

Dar A., Shah A., Bhanja N. and Samantaraya A. (2014), "The relationship between stock prices and exchange rates in Asian markets: A wavelet based correlation and quantile regression approach", South Asian Journal of Global Business Research, 3(2), 209-224. 
Dibooglu S. and Enders W. (2001), "Do real wages respond asymmetrically to unemployment shocks? Evidence from the U.S. and Canada", Journal of Macroeconomics, 23(4), 495-515.

Dornbusch R. and Fisher S. (1980), "Exchange rates and the current account", American Economic Review, 70, 960-971.

Engle R. and Granger C. (1987), "Cointegration and error correction: Representation, estimation and testing", Econometrica, 55(2), 251-276.

Enders W. and Granger C. (1998), "Unit root tests and asymmetric adjustments with an example using the term structure of interest rates", Journal of Business and Economic Studies, 16(3), 304-311.

Enders W. and Silkos P. (2001), “Cointegration and threshold adjustment", Journal of Business and Economic Statistics, 19(2), 166-176.

Fowowe B. (2015), "The relationship between stock prices and exchange rates in South Africa and Nigeria: Structural breaks analysis", International Journal of Applied Economics, 29(1), 1-14.

Franck P. and Young A. (1972), "Stock price reaction of multinational firms to exchange realignments", Financial Management, 1, 66-73.

Frankel J. (1983), "Monetary and portfolio-balances models of exchange rate determination", In J. Bhandari and B. Putnam eds.: Economic Interdependence and Flexible Exchange Rates, MIT Press, Cambridge, Massachusetts, 84-115.

Gavin M. (1989), "The stock market and exchange rate dynamics", Journal of International Money and Finance, 8(2), 181-200. 
Granger C., Huang B. and Yang C. (2000), “A bivariate causality between stock prices and exchange rates: Evidence from the recent Asian flu", The Quarterly Review of Economics and Finance, 40(3), 337-354.

Gregory A. and Hansen B. (1996), "Residual based test for cointegration in models with regime shifts", Journal of Econometrics, 70(1), 199-226.

Hansen B. (1997), "Inference in TAR models", Studies in Nonlinear Dynamics and Econometrics, 2(1), 1-14.

Hansen B. and Seo B. (2002), "Testing for two-regime threshold cointegration in vector error-correction models", Journal of Econometrics, 110(2), 293-318.

Ho L. and Huang C. (2015), "The nonlinear relationships between stock indexes and exchange rates", Japan and the World Economy, 33, 20-27.

Issam S., Abdalla A. and Murinde V. (2007), "Exchange rate and stock price interactions in emerging financial markets: Evidence on India, Korea, Pakistan and the Philippines", Applied Financial Economics, 7(1), 25-35.

Johansen S. (2001), "Estimation and hypothesis testing of cointegration vectors in Gaussian vector autoregressive models", Econometrica, 59(6), 1551-1580.

Jorion P. (1990), “The exchange rate exposure of US multinational”, Journal of Business, 63, $331-345$.

Koulakiotis A., Kiohos A. and Babalos V. (2015), "Exploring the interaction between stock price index and exchange rates; An asymmetric threshold approach", Applied Economics, 47(13), 1273-1285. 
Kumar M. (2009), “A bivariate linear and nonlinear causality between stock prices and exchange rates", Economics Bulletin, 29(4), 2884-2895.

Lean H., Narayan P. and Smyth R. (2011), “The exchange rate and stock price interaction in major Asian markets: Evidence for individual countries and panels allowing for structural breaks", The Singapore Economic Review, 56(2), 255-277.

Liang C., Chen M. and Yang C. (2015), “The interactions of stock prices and exchange rates in the ASEAN-5 countries: New evidence using a bootstrap panel granger causality approach", Global Economic Review, 44(3), 324-334.

Lin C. (2012), "The co-movement between exchange rates stock price in the Asian emerging markets", International Review of Economics and Finance, 22(1), 161-172.

Lo M. and Zivot E. (2001), “Threshold cointegration and nonlinear adjustment to the law of one price", Macroeconomic Dynamics, 5(4), 533-576.

Lo L. and Huang C. (2015), “The nonlinear relationship between stock indexes and exchange rates", Japan and the World Economy, 33, 20-27.

Ma C. and Kao G. (1990), "On exchange rate changes and stock price reactions", Journal of Business Finance and Accounting, 17, 441-449.

Mishra A. (2004), "Stock market and foreign exchange market in India: Are they related?", South Asian Journal of Management, 11(2), 13-31.

Mlambo C., Maredza A. and Sibanda K. (2013), "Effects of exchange rate volatility on the stock market: A case study of South Africa”, Mediterranean Journal of Social Sciences, 4(14), 561-570. 
Mok H. (1993), "Causality of interest rates, exchange rate and stock prices at stock market open and close in Hong Kong”, Asia Pacific Journal of Management, 10(2), 123-143.

Muhammad N., Rasheed A. and Husain F. (2002), "Stock prices and exchange rates: Are they related? Evidence from South Asian countries", The Pakistan Development Review, $41(4), 535-550$

Ndako U. (2013), "Dynaimcs of stock prices and exchange rates relationship: Evidence from five sub-Saharan African financial markets", Journal of African Business, 14(1), 47-57.

Nieh C. and Lee C. (2001), "Dynamic relationship between stock prices and exchange rates for G-7 countries", The Quarterly Review of Economics and Finance, 41, 477-490.

Ocran M. (2010), "South Africa and United States stock prices and the Rand/Dollar exchange rate", South African Journal of Economic and Management Sciences, 3(3), 362-375.

Pan M., Fok S. and Liu Y. (2007), "Dynamic linkages between exchange rates and stock prices: Evidence from East Asian markets", International Review of Economics and Finance, $16(4), 503-520$.

Pesaran M., Shin Y. and Smith R. (2001), "Bounds testing approaches to the analysis of levels relationships", Journal of Applied Econometrics, 16, 289-326.

Phiri A. (2015), "Efficient market hypothesis in South Africa: Evidence from linear and nonlinear unit root tests", Managing Global Transitions, (8)2, 111-124.

Phiri A. (2016), "Is South Africa's inflation target too persistent for monetary policy conduct", International Journal of Sustainable Economy, (8)2, 111-124. 
Phiri A. (2017), "Long-run equilibrium between inflation and stock market returns in South Africa: A nonlinear perspective", International Journal of Sustainable Economy, 9(1), 19-33.

Phiri A. (2018), "Has the South African Reserve Bank responded to equity returns since the sub-prime crisis? An asymmetric convergence approach", International Journal of Sustainable Economy, 10(3), 205-225.

Phylaktis and Ravazzolo F. (2005), "Stock prices and exchange rate dynamics", Journal of International Money and Finance, 24(7), 1031-1053.

Ramasamy B. and Yeung M. (2005), “The causality between stock returns and exchanges rates: Revisited", Australian Economic Papers, 44(2), 162-169.

Shin Y., Yu B. and Greenwood-Nimmo M. (2014), "Modelling asymmetric cointegration and dynamic multipliers in a nonlinear ARDL framework", Festsschrift in honor of Peter Schmidt: Econometric Methods and Applications, eds. By R. Sickels and W. Horace, Springer, 281-314.

Solnik B. (1987), "Using financial prices to test exchange rate models: A note", Journal of Finance, 42, 141-149.

Smith C. (1992), "Stock markets and the exchange rate: A multi-country approach", Journal of Macroeconomics, 14, 607-629.

Smyth R and Nandha M. (2003), "Bivariate causality between exchange rates and stock prices in South Asia", Applied Economic Letters, 10(11), 699-704.

Sui L and Sun L. (2015), "Spillover effects between exchange rates and stock prices: Evidence from BRICS around the recent global financial crisis", Research In International Business and Finance, 36, 459-471. 
Rutledge R., Karim K. and Li C. (2014), “A study of the relationship between Renminbi exchange rates and Chinese stock prices", International Economic Journal, 28(3), 381-403.

Tabak B. (2006), "The dynamic relationship between stock prices and exchange rates: Evidence for Brazil”, International Journal of Theoretical and Applied Finance, 9(8), 13771396.

Tang B. (2018), "Does currency exposure affect stock returns of Chinese automobile firms?", Empirical Economics, (forthcoming).

Tsai I. (2012), “The relationship between stock price index and exchange rate in Asian markets: A quantile regression approach", Journal of International Financial Markets, Institutions and Money, 22(3), 609-621.

Yau H. and Nieh C. (2006), "Interrelationships among stock prices of Taiwan and Japan and NTD/Yen exchange rate”, Journal of Asian Economies, 17(3), 292-300.

Yau H. and Nieh C. (2009), "Testing for cointegration with threshold effect between stock prices and exchange rates in Japan and Taiwan", Japan and the World Economy, 21, 292300.

Yu Q. (1997), "Stock prices and exchange rates: Experiencing in leading East Asian financial centres: Tokyo, Hong Kong and Singapore", Singapore Economic Review, 41(1), 47-56.

Zhao H. (2010), "Dynamic relationship between exchange rate and stock price: Evidence from China", Research in International Business and Finance, 24(2), 103-112. 
Appendix A: Summary of reviewed literature

\begin{tabular}{|c|c|c|c|c|}
\hline $\begin{array}{c}\text { Panel A: } \\
\text { Early studies }\end{array}$ & & & & \\
\hline Author & Country & Period & Methodology & Results \\
\hline $\begin{array}{c}\text { Franck and } \\
\text { Young (1972) }\end{array}$ & $\begin{array}{c}280 \text { US } \\
\text { industrial } \\
\text { corporations }\end{array}$ & $1967-1971$ & $\begin{array}{c}\text { Stock } \\
\text { performance } \\
\text { tests }\end{array}$ & $\begin{array}{c}\text { International } \\
\text { exchange rate } \\
\text { devaluations } \\
\text { had positive } \\
\text { effect on both } \\
\text { low-intensity } \\
\text { and high- } \\
\text { intensity } \\
\text { multinational } \\
\text { firms }\end{array}$ \\
\hline $\begin{array}{c}\text { Ang and } \\
\text { Ghallab (1976) }\end{array}$ & $\begin{array}{c}15 \text { US } \\
\text { multinational } \\
\text { corporations }\end{array}$ & $1969-1973$ & OLS regression & $\begin{array}{c}\text { Stock prices of } \\
10 \text { firms react to } \\
\text { devaluations } \\
\text { whereas the } \\
\text { remaining } 5 \\
\text { firms do not. }\end{array}$ \\
\hline $\begin{array}{c}\text { Aggarwal } \\
(1981)\end{array}$ & $\begin{array}{l}3 \text { US stock } \\
\text { indices }\end{array}$ & $1974-1978$ & OLS regression & $\begin{array}{c}\text { Positive } \\
\text { correlation } \\
\text { between } \\
\text { exchange rates } \\
\text { and stock prices } \\
\text { for all indices }\end{array}$ \\
\hline Solnik (1987) & $\begin{array}{l}\text { Canada, France, } \\
\text { Germany, } \\
\text { Japan, } \\
\text { Netherlands, } \\
\text { Switzerland, } \\
\text { UK and the US }\end{array}$ & $1973-1983$ & $\begin{array}{c}\text { Seemingly } \\
\text { Unrelated } \\
\text { Regression } \\
\text { Equations }\end{array}$ & $\begin{array}{c}\text { Stock returns } \\
\text { differential } \\
\text { positively } \\
\text { affects } \\
\text { exchange rates } \\
\text { for France. } \\
\text { Stock returns } \\
\text { differential } \\
\text { negatively } \\
\text { affects } \\
\text { exchange rates } \\
\text { for Canada, } \\
\text { Germany, } \\
\text { Japan, } \\
\text { Switzerland, the } \\
\text { UK and US, } \\
\text { whereas no } \\
\text { relations exist }\end{array}$ \\
\hline
\end{tabular}




\begin{tabular}{|c|c|c|c|c|}
\hline & & & & $\begin{array}{l}\text { for Netherlands } \\
\text { and Switzerland }\end{array}$ \\
\hline $\begin{array}{c}\text { Ma and Kao } \\
(1990)\end{array}$ & $\begin{array}{l}\text { UK, Canada, } \\
\text { France, } \\
\text { Germany, Italy } \\
\text { and Japan. }\end{array}$ & $1973-1983$ & OLS regression & $\begin{array}{c}\text { Currency } \\
\text { appreciation } \\
\text { negatively } \\
\text { affects stock } \\
\text { prices for } \\
\text { export-oriented } \\
\text { countries whilst } \\
\text { currency } \\
\text { appreciation has } \\
\text { a positive effect } \\
\text { for import- } \\
\text { dominated } \\
\text { countries }\end{array}$ \\
\hline $\begin{array}{c}\text { Bahmani- } \\
\text { Oskooee and } \\
\text { Sohrabian } \\
\text { (1992) }\end{array}$ & US & $1973-1988$ & $\begin{array}{c}\text { Enders and } \\
\text { Granger (1987) } \\
\text { and granger } \\
\text { causality tests }\end{array}$ & $\begin{array}{l}\text { No long-run } \\
\text { relationship } \\
\text { between } \\
\text { exchange rates } \\
\text { and stock prices } \\
\text { only in the } \\
\text { short-run. }\end{array}$ \\
\hline Smith (1992) & $\begin{array}{l}\text { US, Germany } \\
\text { and Japan }\end{array}$ & $1974-1988$ & $\begin{array}{c}\text { Enders and } \\
\text { Granger (1987) }\end{array}$ & $\begin{array}{l}\text { US stocks do } \\
\text { not affect } \\
\text { exchange rates, } \\
\text { Japan stocks } \\
\text { positively affect } \\
\text { exchange rates } \\
\text { and Germany } \\
\text { stocks } \\
\text { negatively } \\
\text { affect exchange } \\
\text { rate }\end{array}$ \\
\hline Mok (1993) & Hong Kong & 1986-1991 & $\begin{array}{c}\text { ARIMA and } \\
\text { granger } \\
\text { causality tests }\end{array}$ & $\begin{array}{l}\text { Bi-directional } \\
\text { causality } \\
\text { between stock } \\
\text { prices and } \\
\text { exchange rates }\end{array}$ \\
\hline \multicolumn{5}{|l|}{$\begin{array}{c}\text { Panel B: } \\
\text { Asian studies }\end{array}$} \\
\hline Author & Country & Period & Methodology & Results \\
\hline $\begin{array}{c}\text { Ajayi and } \\
\text { Mougoue } \\
(1996)\end{array}$ & $\begin{array}{c}\text { Canada, } \\
\text { Germany, } \\
\text { France, Italy, }\end{array}$ & $1985-1991$ & $\begin{array}{c}\text { Granger } \\
\text { causality tests }\end{array}$ & $\begin{array}{c}\text { Stock prices } \\
\text { lead exchange } \\
\text { rates in Canada, }\end{array}$ \\
\hline
\end{tabular}




\begin{tabular}{|c|c|c|c|c|}
\hline & $\begin{array}{l}\text { Japan, UK, US, } \\
\text { Taiwan, Korea, } \\
\text { Philippines, } \\
\text { Malaysia, } \\
\text { Singapore, } \\
\text { Hong Kong, } \\
\text { Indonesia and } \\
\text { Thailand }\end{array}$ & & & $\begin{array}{l}\text { Germany, } \\
\text { France, Italy, } \\
\text { Japan, UK, } \\
\text { Taiwan, } \\
\text { Indonesia, } \\
\text { Philippines; } \\
\text { exchange rates } \\
\text { lead stock } \\
\text { prices for Korea } \\
\text { and no causality } \\
\text { for remaining } \\
\text { countries }\end{array}$ \\
\hline $\begin{array}{c}\text { Abdalla and } \\
\text { Murinde (1997) }\end{array}$ & $\begin{array}{l}\text { India, Korea, } \\
\text { Pakistan and the } \\
\text { Philippines }\end{array}$ & 1985-1994 & VAR & $\begin{array}{c}\text { Exchange rate } \\
\text { granger causes } \\
\text { stock prices in } \\
\text { all countries } \\
\text { except } \\
\text { Philippines }\end{array}$ \\
\hline $\begin{array}{l}\text { Ajayi et al. } \\
\text { (1998) }\end{array}$ & $\begin{array}{c}\text { Canada, } \\
\text { Germany, } \\
\text { France, Italy, } \\
\text { Japan, UK, US, } \\
\text { Taiwan, Korea, } \\
\text { Philippines, } \\
\text { Malaysia, } \\
\text { Singapore, } \\
\text { Hong Kong, } \\
\text { Indonesia and } \\
\text { Thailand }\end{array}$ & $1985-1991$ & $\begin{array}{l}\text { Granger } \\
\text { causality }\end{array}$ & $\begin{array}{c}\text { Uni-direction } \\
\text { causality from } \\
\text { stock prices to } \\
\text { exchange rates } \\
\text { for Canada, } \\
\text { Germany, } \\
\text { France, Italy, } \\
\text { Japan, UK, } \\
\text { Hong Kong. } \\
\text { Taiwan, } \\
\text { Thailand, } \\
\text { Indonesia, } \\
\text { Malaysia, } \\
\text { Philippines. } \\
\text { Uni-direction } \\
\text { causality from } \\
\text { exchange rates } \\
\text { to stock prices } \\
\text { for Korea, }\end{array}$ \\
\hline $\begin{array}{c}\text { Granger et al. } \\
(2000)\end{array}$ & $\begin{array}{l}\text { Hong Kong, } \\
\text { Indonesia, } \\
\text { Japan, South } \\
\text { Korea, } \\
\text { Malaysia, the } \\
\text { Philippines, } \\
\text { Singapore, }\end{array}$ & 1986-1998 & VAR & $\begin{array}{c}\text { Feedback } \\
\text { causality } \\
\text { between } \\
\text { exchange rates } \\
\text { and stock } \\
\text { returns for all } \\
\text { countries except }\end{array}$ \\
\hline
\end{tabular}




\begin{tabular}{|c|c|c|c|c|}
\hline & $\begin{array}{c}\text { Thailand and } \\
\text { Taiwan }\end{array}$ & & & $\begin{array}{l}\text { Indonesia and } \\
\text { Japan were } \\
\text { there no } \\
\text { causality effects }\end{array}$ \\
\hline $\begin{array}{l}\text { Nieh and Lee } \\
\qquad(2001)\end{array}$ & G7 & 1993-1996 & $\begin{array}{c}\text { E-G and } \\
\text { Johansen } \\
\text { VECM } \\
\text { approach }\end{array}$ & $\begin{array}{c}\text { E-G method } \\
\text { finds } \\
\text { cointegration } \\
\text { only for } \\
\text { Germany } \\
\text { whereas VECM } \\
\text { model finds } \\
\text { cointegration } \\
\text { effects for all } \\
\text { G7 countries }\end{array}$ \\
\hline $\begin{array}{c}\text { Smyth and } \\
\text { Nanda (2003) }\end{array}$ & $\begin{array}{l}\text { Bangladesh, } \\
\text { India, Pakistan } \\
\text { and Sri Lanka }\end{array}$ & $1995-2001$ & $\begin{array}{c}\text { Johansen (1991) } \\
\text { VECM } \\
\text { approach and } \\
\text { granger } \\
\text { causality test }\end{array}$ & $\begin{array}{l}\text { No long-run } \\
\text { cointegration } \\
\text { relationship } \\
\text { between } \\
\text { exchange rates } \\
\text { and stock } \\
\text { returns for all } \\
\text { countries }\end{array}$ \\
\hline Mishra (2004) & India & $1992-2002$ & $\begin{array}{c}\text { VAR and } \\
\text { granger } \\
\text { causality tests }\end{array}$ & $\begin{array}{l}\text { No causality } \\
\text { effects between } \\
\text { stock returns } \\
\text { and exchange } \\
\text { rate } \\
\end{array}$ \\
\hline $\begin{array}{l}\text { Ramasamy and } \\
\text { Yeung (2005) }\end{array}$ & India & $1997-2000$ & $\begin{array}{c}\text { Granger } \\
\text { causality tests }\end{array}$ & $\begin{array}{l}\text { Direction of } \\
\text { causality } \\
\text { dependent on } \\
\text { the time period } \\
\text { examined }\end{array}$ \\
\hline $\begin{array}{l}\text { Phylaktis and } \\
\text { Ravazzolo } \\
(2005)\end{array}$ & $\begin{array}{l}\text { Hong Kong, } \\
\text { Malaysia, } \\
\text { Singapore, } \\
\text { Thailand and } \\
\text { Philippines. }\end{array}$ & $1980-1998$ & $\begin{array}{c}\text { Johansen (1991) } \\
\text { VECM } \\
\text { approach and } \\
\text { granger } \\
\text { causality }\end{array}$ & $\begin{array}{c}\text { Significant } \\
\text { cointegration } \\
\text { effects between } \\
\text { exchange rates } \\
\text { and stock } \\
\text { returns for all } \\
\text { countries }\end{array}$ \\
\hline $\begin{array}{c}\text { Yau and Nieh } \\
(2006)\end{array}$ & $\begin{array}{c}\text { Taiwan and } \\
\text { Japan }\end{array}$ & $1991-2005$ & $\begin{array}{c}\text { Johansen (1991) } \\
\text { VECM } \\
\text { approach and } \\
\text { granger } \\
\text { causality }\end{array}$ & $\begin{array}{l}\text { No significant } \\
\text { cointegration or } \\
\text { causality effects } \\
\text { for both } \\
\text { countries }\end{array}$ \\
\hline
\end{tabular}




\begin{tabular}{|c|c|c|c|c|}
\hline Liu et al. (2007) & $\begin{array}{c}\text { Malaysia, } \\
\text { Singapore, } \\
\text { Korea, } \\
\text { Philippines, } \\
\text { Japan, Germany } \\
\text { and the UK. }\end{array}$ & $1985-2015$ & $\begin{array}{c}\text { DCC- } \\
\text { MGARCH }\end{array}$ & $\begin{array}{l}\text { Negative } \\
\text { Significant } \\
\text { relations for } \\
\text { Malaysia, } \\
\text { Singapore, } \\
\text { Korea, the UK } \\
\text { whilst } \\
\text { insignificant } \\
\text { relations for } \\
\text { Philippines, } \\
\text { Japan, } \\
\text { Germany. }\end{array}$ \\
\hline Pan et al. (2007) & $\begin{array}{l}\text { Hong Kong, } \\
\text { Japan, Korea, } \\
\text { Malaysia, } \\
\text { Singapore, } \\
\text { Taiwan and } \\
\text { Thailand }\end{array}$ & $1988-1998$ & $\begin{array}{c}\text { VECM and } \\
\text { granger } \\
\text { causality tests }\end{array}$ & $\begin{array}{c}\text { Cointegration } \\
\text { relations only } \\
\text { for Hong Kong, } \\
\text { Japan, Taiwan } \\
\text { and Thailand } \\
\text { whereas no } \\
\text { cointegration } \\
\text { relations for } \\
\text { remaining } \\
\text { countries. }\end{array}$ \\
\hline Zhao (2010) & China & 1991-2009 & $\begin{array}{l}\text { VAR and } \\
\text { MGARCH }\end{array}$ & $\begin{array}{l}\text { Bidirectional } \\
\text { spillovers } \\
\text { between } \\
\text { exchange rates } \\
\text { and stock } \\
\text { markets }\end{array}$ \\
\hline $\begin{array}{l}\text { Lean et al. } \\
\quad(2011)\end{array}$ & $\begin{array}{l}\text { Hong Kong, } \\
\text { Indonesia, } \\
\text { Japan, Korea, } \\
\text { Malaysia, the } \\
\text { Philippines, } \\
\text { Singapore and } \\
\text { Thailand }\end{array}$ & $1991-2005$ & $\begin{array}{c}\text { Gregory and } \\
\text { Hansen (1996) } \\
\text { cointegration } \\
\text { with structural } \\
\text { break }\end{array}$ & $\begin{array}{l}\text { No-long run } \\
\text { cointegration } \\
\text { between } \\
\text { exchange rate- } \\
\text { stock prices but } \\
\text { there exist bi- } \\
\text { directional } \\
\text { short-run } \\
\text { causality effects }\end{array}$ \\
\hline Lin (2012) & $\begin{array}{l}\text { Philippines, } \\
\text { Thailand, } \\
\text { Indonesia, } \\
\text { India, Korea } \\
\text { and Taiwan. }\end{array}$ & $1986-2010$ & ARDL & $\begin{array}{l}\text { No significant } \\
\text { cointegration } \\
\text { relations except } \\
\text { for during the } \\
\text { Asian crisis } \\
\text { period for } \\
\text { Indonesia, the }\end{array}$ \\
\hline
\end{tabular}




\begin{tabular}{|c|c|c|c|c|}
\hline & & & & $\begin{array}{l}\text { Philippines and } \\
\text { Thailand. }\end{array}$ \\
\hline $\begin{array}{l}\text { Liang et al. } \\
\text { (2013) }\end{array}$ & $\begin{array}{l}\text { Indonesia, } \\
\text { Malaysia, } \\
\text { Philippines, } \\
\text { Singapore and } \\
\text { Thailand }\end{array}$ & $2008-2011$ & $\begin{array}{l}\text { DOLS and } \\
\text { panel granger } \\
\text { causality tests }\end{array}$ & $\begin{array}{c}\text { Causality } \\
\text { running from } \\
\text { exchange rates } \\
\text { to stock prices }\end{array}$ \\
\hline $\begin{array}{l}\text { Liang et al. } \\
\text { (2015) }\end{array}$ & $\begin{array}{l}\text { Indonesia, } \\
\text { Malaysia, } \\
\text { Philippines, } \\
\text { Singapore and } \\
\text { Thailand }\end{array}$ & $2000-2013$ & $\begin{array}{c}\text { Bootstrap panel } \\
\text { granger } \\
\text { causality }\end{array}$ & $\begin{array}{c}\text { Stock prices } \\
\text { lead exchange } \\
\text { rates in } \\
\text { Malaysia, } \\
\text { Philippines, } \\
\text { Thailand; } \\
\text { exchange rates } \\
\text { lead to stock } \\
\text { prices in } \\
\text { Indonesia and } \\
\text { no causality for } \\
\text { Singapore }\end{array}$ \\
\hline $\begin{array}{l}\text { Rutledge et al. } \\
\quad(2014)\end{array}$ & $\begin{array}{l}\text { 10 Chinese } \\
\text { industries }\end{array}$ & $2001-2011$ & VECM & $\begin{array}{l}\text { Significant } \\
\text { cointegation } \\
\text { relations in all } \\
\text { industries. }\end{array}$ \\
\hline \multicolumn{5}{|l|}{$\begin{array}{c}\text { Panel C: } \\
\text { South African } \\
\text { studies }\end{array}$} \\
\hline Author & Country & Period & Methodology & Results \\
\hline Ocran (2010) & South Africa & 1986-2006 & VECM & $\begin{array}{c}\text { Causality from } \\
\text { US stocks to } \\
\text { ZAR/US rate } \\
\text { but no causality } \\
\text { between JSE } \\
\text { and ZAR/US } \\
\text { rate }\end{array}$ \\
\hline $\begin{array}{l}\text { Adjasi et al. } \\
\text { (2011) }\end{array}$ & $\begin{array}{l}\text { Egypt, Ghana, } \\
\text { Kenya, } \\
\text { Mauritius, } \\
\text { Nigeria, Tunisia } \\
\text { and South } \\
\text { Africa. }\end{array}$ & $1995-2004$ & $\begin{array}{c}\text { Johansen (1991) } \\
\text { VECM } \\
\text { approach and } \\
\text { granger } \\
\text { causality }\end{array}$ & $\begin{array}{c}\text { No } \\
\text { cointegration } \\
\text { effects for all } \\
\text { countries except } \\
\text { Tunisia. }\end{array}$ \\
\hline $\begin{array}{c}\text { Alam et al. } \\
\text { (2011) }\end{array}$ & South Africa & $2000-2004$ & $\begin{array}{c}\text { Johansen (1991) } \\
\text { VECM } \\
\text { approach and } \\
\text { granger }\end{array}$ & $\begin{array}{c}\text { Significant } \\
\text { cointegration } \\
\text { effects but no } \\
\text { causality }\end{array}$ \\
\hline
\end{tabular}




\begin{tabular}{|c|c|c|c|c|}
\hline & & & causality & effects. \\
\hline Ndako (2013) & $\begin{array}{c}\text { Ghana, Kenya, } \\
\text { Mauritius, } \\
\text { Nigeria and } \\
\text { South Africa }\end{array}$ & $2000-2009$ & $\begin{array}{c}\text { Johansen (1991) } \\
\text { VECM } \\
\text { approach and } \\
\text { DCC-GARCH }\end{array}$ & $\begin{array}{l}\text { Lack of long- } \\
\text { run relationship } \\
\text { in all five } \\
\text { countries. }\end{array}$ \\
\hline $\begin{array}{l}\text { Mlambo et al. } \\
\text { (2013) }\end{array}$ & South Africa & $2000-2010$ & GARCH & $\begin{array}{c}\text { Weak } \\
\text { relationship } \\
\text { between } \\
\text { exchange rate } \\
\text { volatility and } \\
\text { stock returns. }\end{array}$ \\
\hline $\begin{array}{l}\text { Sui and Sun } \\
\quad(2015)\end{array}$ & $\begin{array}{l}\text { Brazil, Russian, } \\
\text { India, China } \\
\text { and South } \\
\text { Africa }\end{array}$ & 1993-2014 & ARDL & $\begin{array}{c}\text { Significant } \\
\text { cointegration } \\
\text { for Brazil, } \\
\text { Russia and } \\
\text { China but not } \\
\text { for India and } \\
\text { South Africa }\end{array}$ \\
\hline Fowowe (2015) & $\begin{array}{l}\text { South Africa } \\
\text { and Nigeria }\end{array}$ & $2003-2013$ & $\begin{array}{c}\text { Johansen (1991) } \\
\text { VECM } \\
\text { approach and } \\
\text { Gregory and } \\
\text { Hansen (1996) } \\
\text { cointegration } \\
\text { with structural } \\
\text { break }\end{array}$ & $\begin{array}{c}\text { No } \\
\text { cointegration in } \\
\text { Nigeria; } \\
\text { significant } \\
\text { cointegration in } \\
\text { South Africa } \\
\text { but no causality } \\
\text { effects } \\
\end{array}$ \\
\hline $\begin{array}{l}\text { Dahir et al. } \\
\text { (2017) }\end{array}$ & $\begin{array}{l}\text { Brazil, Russian, } \\
\text { India, China } \\
\text { and South } \\
\text { Africa }\end{array}$ & 2006-2016 & $\begin{array}{l}\text { Wavelet } \\
\text { analysis }\end{array}$ & $\begin{array}{l}\text { Exchange rates } \\
\text { lead to stock } \\
\text { returns in Brazil } \\
\text { and Russia; } \\
\text { stock returns } \\
\text { lead to } \\
\text { exchange rates } \\
\text { in India, } \\
\text { bidirectional } \\
\text { causality in } \\
\text { South Africa } \\
\text { and no } \\
\text { correlation for } \\
\text { China. } \\
\end{array}$ \\
\hline \multicolumn{5}{|l|}{$\begin{array}{c}\text { Panel D: } \\
\text { Nonlinear } \\
\text { studies } \\
\end{array}$} \\
\hline Author & Country & Period & Methodology & Results \\
\hline
\end{tabular}




\begin{tabular}{|c|c|c|c|c|}
\hline Tabak (2006) & Brazil & & $\begin{array}{c}\text { Nonlinear } \\
\text { causality tests }\end{array}$ & $\begin{array}{c}\text { Exchange rates } \\
\text { lead stock } \\
\text { prices }\end{array}$ \\
\hline Kumar (2009) & India & 1999-2009 & $\begin{array}{c}\text { Nonlinear } \\
\text { causality tests }\end{array}$ & $\begin{array}{l}\text { Bi-directional } \\
\text { causality } \\
\text { between } \\
\text { exchange rates } \\
\text { and stock prices }\end{array}$ \\
\hline $\begin{array}{c}\text { Yau and Nieh } \\
\text { (2009) }\end{array}$ & $\begin{array}{c}\text { Japan and } \\
\text { Taiwan }\end{array}$ & $1991-2008$ & MTAR & \\
\hline Tsai (2012) & $\begin{array}{l}\text { Singapore, } \\
\text { Thailand, } \\
\text { Malaysia, } \\
\text { Philippines, } \\
\text { South Korea } \\
\text { and Taiwan. }\end{array}$ & $1992-2009$ & $\begin{array}{l}\text { Quantile } \\
\text { regression }\end{array}$ & $\begin{array}{c}\text { Negative } \\
\text { relationship } \\
\text { between } \\
\text { exchange rates } \\
\text { and stock prices } \\
\text { in all regression } \\
\text { quantiles }\end{array}$ \\
\hline $\begin{array}{c}\text { Cakan and Ejra } \\
\text { (2013) }\end{array}$ & $\begin{array}{l}\text { Turkey, } \\
\text { Thailand, } \\
\text { Brazil, India, } \\
\text { Indonesia, } \\
\text { Korea, Mexico, } \\
\text { Philippines, } \\
\text { Poland, Russia, } \\
\text { Singapore and } \\
\text { Taiwan. }\end{array}$ & $1994-2010$ & $\begin{array}{c}\text { Nonlinear } \\
\text { causality tests }\end{array}$ & $\begin{array}{l}\text { Only significant } \\
\text { cointegration } \\
\text { effects for } \\
\text { Turkey, Brazil } \\
\text { and Russia with } \\
\text { bi-directional } \\
\text { causality in } \\
\text { these countries. }\end{array}$ \\
\hline $\begin{array}{c}\text { Chkili and } \\
\text { Nguyen (2014) }\end{array}$ & $\begin{array}{l}\text { Brazil, Russia, } \\
\text { India, China } \\
\text { and South } \\
\text { Africa }\end{array}$ & $1997-2013$ & $\begin{array}{c}\text { Markov } \\
\text { Switching VAR }\end{array}$ & $\begin{array}{c}\text { Regime } \\
\text { switching } \\
\text { regime for } \\
\text { Brazil, Russia, } \\
\text { India and South } \\
\text { Africa }\end{array}$ \\
\hline Dar et al. (2014) & $\begin{array}{l}\text { India, Pakistan, } \\
\text { Bangladesh, Sri } \\
\text { Lanka, } \\
\text { Malaysia, } \\
\text { Indonesia, } \\
\text { Philippines and } \\
\text { Thailand }\end{array}$ & $1996-2013$ & $\begin{array}{c}\text { Wavelet based } \\
\text { correlation and } \\
\text { quantile } \\
\text { regression }\end{array}$ & $\begin{array}{c}\text { Negative } \\
\text { relationship } \\
\text { between } \\
\text { exchange rates } \\
\text { and stock prices } \\
\text { across all } \\
\text { quantiles }\end{array}$ \\
\hline Ali et al. (2015) & South Africa & $1980-2014$ & MTAR & $\begin{array}{c}\text { Positive } \\
\text { relationship } \\
\text { between } \\
\text { exchange rates } \\
\text { and stock prices }\end{array}$ \\
\hline
\end{tabular}




\begin{tabular}{|c|c|c|c|c|}
\hline & & & & $\begin{array}{c}\text { with } \\
\text { asymmetric } \\
\text { speed of } \\
\text { adjustment. }\end{array}$ \\
\hline $\begin{array}{l}\text { Koulakiotis et } \\
\text { al. (2015) }\end{array}$ & $\begin{array}{c}\text { USA, Canada } \\
\text { and UK }\end{array}$ & $1990-2014$ & $\begin{array}{l}\text { Asymmetric } \\
\text { cointegration }\end{array}$ & $\begin{array}{c}\text { For USA, } \\
\text { decrease in } \\
\text { stock prices } \\
\text { causes } \\
\text { exchange rate } \\
\text { appreciation, } \\
\text { increase in } \\
\text { stock prices } \\
\text { causes } \\
\text { exchange rate } \\
\text { depreciation. } \\
\text { For Canada, } \\
\text { both decreases } \\
\text { and increases in } \\
\text { stock prices } \\
\text { causes } \\
\text { exchange rate } \\
\text { appreciation. } \\
\text { For the UK, } \\
\text { both decreases } \\
\text { and increases in } \\
\text { stock prices } \\
\text { causes } \\
\text { exchange rate } \\
\text { depreciation. }\end{array}$ \\
\hline $\begin{array}{l}\text { Ho and Huang } \\
\text { (2015) }\end{array}$ & $\begin{array}{l}\text { Brazil, Russia, } \\
\text { India and China }\end{array}$ & $2002-2013$ & $\begin{array}{l}\text { LM test for } \\
\text { causality in } \\
\text { variance }\end{array}$ & $\begin{array}{l}\text { Causality from } \\
\text { exchange rate to } \\
\text { stock prices for } \\
\text { Brazil and } \\
\text { India, Bi- } \\
\text { directional } \\
\text { causality for } \\
\text { Russia and no } \\
\text { causality for } \\
\text { China. }\end{array}$ \\
\hline $\begin{array}{c}\text { Bahmani- } \\
\text { Oskooee and } \\
\text { Saha (2015) }\end{array}$ & US & $1973-2014$ & N-ARDL & $\begin{array}{l}\text { No significant } \\
\text { exchange rate- } \\
\text { stock price } \\
\text { relations }\end{array}$ \\
\hline Bahmani- & Brazil, Canada, & 1994-2014 & N-ARDL & For the USA \\
\hline
\end{tabular}




\begin{tabular}{|c|c|c|c|c|}
\hline $\begin{array}{l}\text { Oskooee and } \\
\text { Saha (2016) }\end{array}$ & $\begin{array}{c}\text { Chile, } \\
\text { Indonesia, } \\
\text { Japan, Korea, } \\
\text { Malaysia, } \\
\text { Mexico and the } \\
\text { UK. }\end{array}$ & & & $\begin{array}{c}\text { and Malaysia, } \\
\text { exchange rate } \\
\text { appreciation } \\
\text { increases stock } \\
\text { returns, } \\
\text { exchange rate } \\
\text { depreciation has } \\
\text { no significant } \\
\text { effect on stock } \\
\text { returns. For } \\
\text { Canada, Chile, } \\
\text { Indonesia and } \\
\text { Japan, there are } \\
\text { no significant } \\
\text { effects. For } \\
\text { Korea, } \\
\text { exchange rate } \\
\text { depreciation } \\
\text { decreases in } \\
\text { stock returns, } \\
\text { exchange rate } \\
\text { appreciation has } \\
\text { no significant } \\
\text { effect on stock } \\
\text { returns. For } \\
\text { Mexico, } \\
\text { exchange rate } \\
\text { appreciation } \\
\text { decreases stock } \\
\text { returns, } \\
\text { exchange rate } \\
\text { depreciation has } \\
\text { no significant } \\
\text { effect on stock } \\
\text { returns }\end{array}$ \\
\hline $\begin{array}{l}\text { Cuestas and } \\
\text { Tang (2017) }\end{array}$ & $\begin{array}{l}31 \text { Chinese } \\
\text { industries }\end{array}$ & $1996-2015$ & N-ARDL & $\begin{array}{l}\text { No insignificant } \\
\text { asymmetric } \\
\text { relationships for } \\
\text { all industries }\end{array}$ \\
\hline $\begin{array}{c}\text { Bahmani- } \\
\text { Oskooee and } \\
\text { Saha (2018) }\end{array}$ & $\begin{array}{c}\text { Argentina, } \\
\text { Australia, } \\
\text { Austria, } \\
\text { Belgium, } \\
\text { Brazil, Canada, }\end{array}$ & $1984-2014$ & N-ARDL & $\begin{array}{c}\text { For the } \\
\text { Argentina, } \\
\text { Malaysia } \\
\text { exchange rate } \\
\text { appreciation }\end{array}$ \\
\hline
\end{tabular}




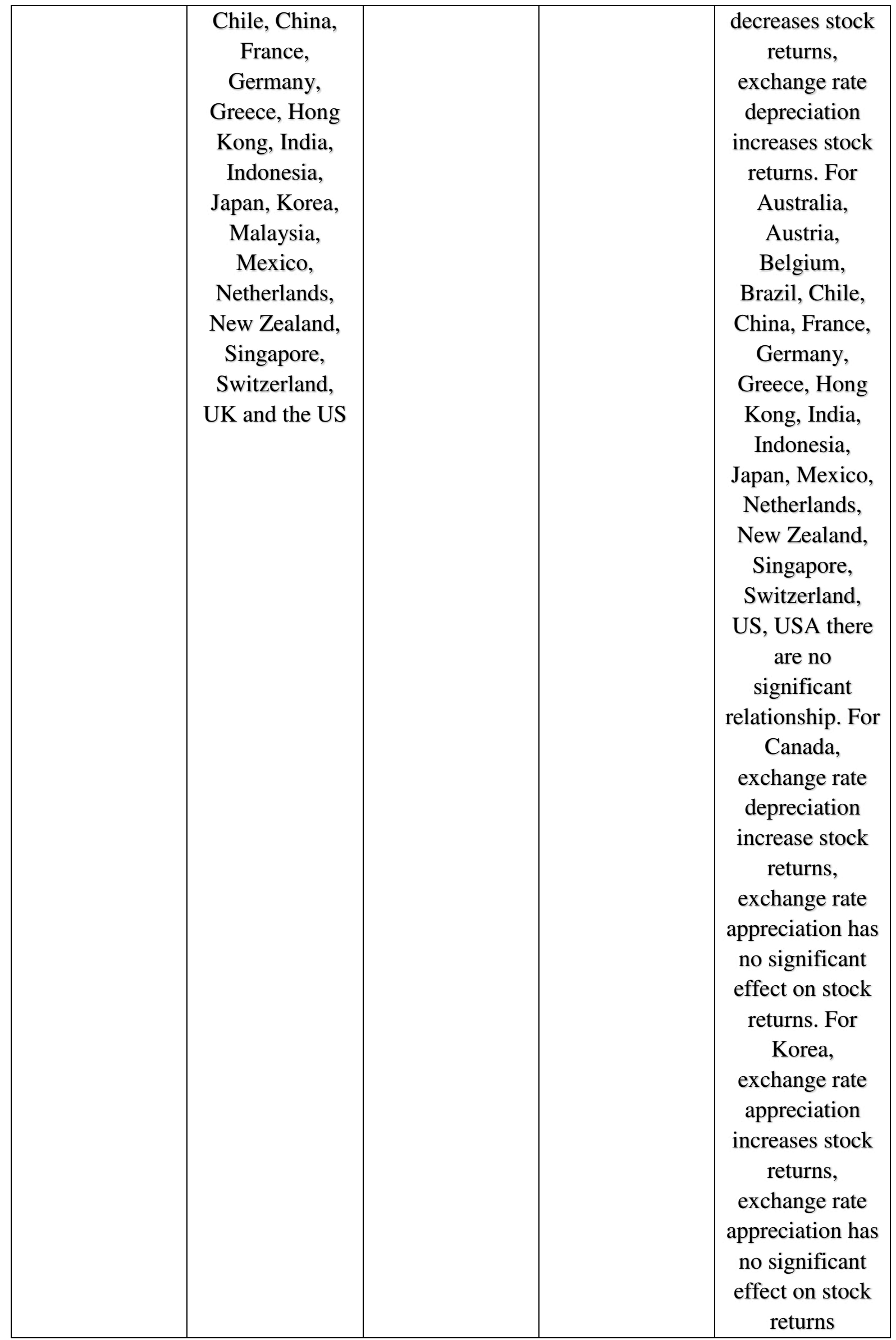




\begin{tabular}{|c|c|c|c|c|}
\hline Tang (2018) & $\begin{array}{l}87 \text { Chinese auto } \\
\text { firms }\end{array}$ & 1994-2016 & N-ARDL & $\begin{array}{c}\text { For Fortune } 500 \\
\text { firms, exchange } \\
\text { rate } \\
\text { appreciation } \\
\text { causes decrease } \\
\text { in stock returns, } \\
\text { exchange rate } \\
\text { depreciation } \\
\text { causes increase } \\
\text { in stock prices. } \\
\text { For B-share } \\
\text { firms, both } \\
\text { exchange rate } \\
\text { appreciation } \\
\text { and } \\
\text { depreciations } \\
\text { causes increase } \\
\text { in stock returns }\end{array}$ \\
\hline
\end{tabular}

